\title{
ÁFRICA EN SEVILLA: LA EXHIBICIÓN COLONIAL DE LA EXPOSICIÓN IBEROAMERICANA DE $1929^{1}$
}

\author{
LUIS ÁNGEL SÁNCHEZ GÓMEZ \\ Facultad de Geografía e Historia - Universidad Complutense
}

\begin{abstract}
RESUMEN: Durante la Exposición Iberoamericana celebrada en Sevilla en 1929-1930 se organizó una exhibición colonial que apenas ha interesado a la historiografía. Allí se mostraron al público las dos principales posesiones españolas en África: el protectorado de Marruecos y la Guinea española. Además de describir los correspondientes pabellones -y lo que en ellos se exbibe-y de contextualizar adecuadamente la exposición en relación con eventos similares contemporáneos, el propósito de este artículo es mostrar los diferentes modelos de exbibición que la administración escenifica en relación con ambos territorios, que incluyen la "exhibición» de nativos guineanos y marroquies. Comprobaremos cómo la exposición deja entrever tanto las limitaciones de ambos procesos de colonización como la imposibilidad de articular un nuevo modelo de imperialismo hispano-africano.
\end{abstract}

PALABRAS ClAVE: Exposición iberoamericana. exposición internacional. exhibición colonial. colonialismo. Marruecos. Guinea Ecuatorial.

ABSTRACT: In the Exposicion Iberoamericana - the Ibero-American Exposition- of Seville in 1929-1930, an interesting colonial exhibition was organized which bas been bitherto unstudied. It was arranged in two sections: the Spanish protectorate of Morocco and Spanish Guinea. The present paper describes both colonial pavilions and the products and collections displayed there, and it compares this exhibition to similar contemporary events. We will analyse the two different expository models adopted by the Spanish administration in regard to each colonial territory, models which also included the «exhibition» of Guinean and Moroccan natives. Finally, we will see how the exhibition suggests the limitations of each of these processes of colonization as well as the impossibility of articulating a new model of Hispanic-African imperialism.

KEY WORDS: Ibero-American Exhibition. International Exhibition. Colonial Exhibition. Colonialism. Morocco. Equatorial Guinea.

${ }^{1}$ Estudio realizado en el ámbito del proyecto de investigación titulado «Imperios, pueblos y colonias en las exposiciones universales: una aproximación al caso español», dirigido por el autor y financiado por el Ministerio de Ciencia y Tecnología (ref. BHA2003-02264). Agradezco a Eloy Martín Corrales sus indicaciones bibliográficas y a los evaluadores anónimos consultado por la revista Hispania sus comentarios y sugerencias. 


\section{INTRODUCCIÓN}

En 1887 tuvo lugar en el Parque del Retiro madrileño la conocida Exposición General de Filipinas, una de las primeras y más relevantes exhibiciones oficiales de carácter colonial organizadas en Europa ${ }^{2}$; poco faltó, sin embargo, para que fuera no sólo la primera sino también la última exposición de esas características celebrada en España ${ }^{3}$. Únicamente se puede mencionar un segundo ejemplo de certamen en apariencia similar — aunque en esencia muy diferente - organizado dentro de nuestras fronteras: las secciones correspondientes al protectorado de Marruecos y a la Guinea española levantadas en Sevilla con motivo de la Exposición Iberoamericana de 1929-19304.

El sevillano fue sólo uno de los dos eventos inaugurados en 1929 bajo la denominación oficial de «Exposición General de España». El otro, la «Exposición Internacional» propiamente dicha, tuvo su sede en Barcelona. Pese a esta aparente y formal coordinación, nunca existió el proyecto de organizar una exposición compartida, sino que se desembocó en ello por la confluencia temporal de dos diseños expositivos que habían tenido orígenes y desarrollos muy diferentes; de hecho, es ya en una fecha muy avanzada, el 7 de junio de 1926, cuando el gobierno de Primo de Rivera determina que ambas exposiciones queden vinculadas de forma oficial ${ }^{5}$.

Pese a que las dos exposiciones, quizás algo más la barcelonesa que la sevillana, suelen ser citadas en las historias generales de las exposiciones internacionales y universales, y aunque existe una bibliografía relativamente extensa que estudia tanto sus orígenes como la repercusión que tuvo la celebración de ambos eventos en la evolución urbana y sociopolítica de las dos capitales, sorprende que sea tan escaso el número de estudios generales e incluso el de artí-

2 Cf. SÁNChez Gómez, Luis Ángel: Un imperio en la vitrina: el colonialismo español en el Pacífico y la Exposición de Filipinas de 1887, Madrid, Consejo Superior de Investigaciones Científicas, 2003.

${ }^{3}$ En 1888 se celebra en Barcelona la primera exposición universal española. No se organiza entonces ningún espacio expositivo que pueda ser vinculado con una exhibición colonial viva propiamente dicha, ni siquiera en la sección dedicada a Filipinas, en la que únicamente están presentes varias cigarreras tagalas en su condición de trabajadoras de la Compañía General de Tabacos de Filipinas.

${ }^{4}$ Durante las décadas de 1930, 1940 y 1950 se organizan exposiciones artísticas, comerciales y turístico-comerciales sobre el protectorado en tierras marroquíes y en diversas ciudades españolas. Además, también se documenta la participación de Marruecos en ferias internacionales de muestras, sobre todo en la de Barcelona. Sin embargo, esos certámenes no pueden ser considerados exhibiciones coloniales propiamente dichas. Se encuentra información general sobre algunos de estos eventos en BELLIDO GANT, María Luisa: «Difundir una identidad: la promoción exterior de Marruecos» en F. Castro Morales (ed.) Al-Andalus: Una identidad compartida. Arte, ideología y enseñanza en el Protectorado Español en Marruecos, Madrid, Universidad Carlos III, Boletín Oficial del Estado (1999) pp. 75-90.

5 Cf. Solano Sobrado, María Teresa: «Antecedentes históricos de la Exposición Iberoamericana de Sevilla» en Cuadernos de Historia Moderna y Contemporánea (Madrid) 7 (1986) pp. 163-187. 
culos especializados que se han publicado acerca de sus respectivos desarrollos y contenidos. Y si hablamos de la exposición de Sevilla, llama poderosamente la atención el poco interés que ha suscitado su parcela colonial. De hecho, salvo un par de artículos que abordan de forma parcial el estudio de dicha sección, las historias generales y los trabajos puntuales redactados sobre el certamen hispalense se contentan con anotar la existencia de ambos pabellones coloniales y con describir en apenas tres o cuatro líneas sus contenidos ${ }^{6}$.

\section{LOS PORQUÉS DE UNA EXHIBICIÓN COLONIAL EN SEVILLA}

Antes de adentrarnos en el estudio de la organización y los contenidos de la exhibición colonial sevillana de 1929, puede ser útil responder a dos interrogantes previos. En primer lugar, al de por qué se determina presentar los territorios africanos de dominio español en una exposición internacional; en segundo, al de por qué se opta por hacerlo en la exposición de Sevilla y no en la de Barcelona. Afrontaremos primero la última cuestión, que en principio parece más sencilla de resolver.

Como ya hemos adelantado, los dos certámenes de 1929 se gestan de forma completamente independiente; el sevillano tiene, además, un desarrollo especialmente largo y tedioso. Se suele citar el año de 1905 — tras la clausura de una exposición local muy aplaudida - como el momento en el que se atisba por vez primera en Sevilla la idea de que en un futuro más o menos lejano pueda organizarse allí una exposición internacional ${ }^{7}$. Si se habla de un certamen «internacional» es porque no existe intención alguna de diseñar una exposición propiamente universal, ya que desde el primer momento el ámbito de referencia es el mundo hispanoamericano, luego ampliado al iberoamericano. $\mathrm{Y}$ esto es así porque el motor que parece mover estas iniciativas es el de un cierto regeneracionismo, que trataría de renovar o despabilar el decaído «espíritu nacional» tras el Desastre de 1898, retomando de alguna forma la intensa proyec-

${ }^{6}$ Además de algún breve artículo de divulgación, hemos revisado los siguientes estudios: Braojos Garrido, Alfonso: Alfonso XIII y la exposición Iberoamericana de Sevilla de 1929, Sevilla, Universidad de Sevilla, 1992; RODRíguez BERNAL, Eduardo: Historia de la Exposición IberoAmericana de Sevilla de 1929, Sevilla, Servicio de Publicaciones del Ayuntamiento de Sevilla, 1994; SALAS, Nicolás: Sevilla en tiempos de la Exposición Iberoamericana 1905-1930. La ciudad del siglo XX, 450 estampas históricas, Sevilla, RD Editores, 2004; TRILlo DE LeYVA, Manuel: La Exposición Iberoamericana: la transformación urbana de Sevilla, Sevilla, Servicio de Publicaciones del Excmo. Ayuntamiento de Sevilla, 1980; Villar Movellán, Alberto: Arquitectura del Regionalismo en Sevilla (1900-1935), Sevilla, Excma. Diputación Provincial de Sevilla, 1979; VILlar Movellán, Alberto: «Los pabellones de la Exposición Iberoamericana» en Francisco Molina (coord.), La Exposición Iberoamericana de 1929: fondos de la Hemeroteca Municipal de Sevilla, Sevilla, Obra Cultural del Monte de Piedad y Caja de Ahorros de Sevilla (1987) [sin paginar].

7 Utilizamos la información que ofrece SOLANO SOBRADO, Op. cit, que hace una presentación muy correcta de los antecedentes históricos de la exposición sevillana de 1929. 
ción americana de Sevilla anterior a la independencia de las colonias. Por supuesto, existen razones de índole económico-comercial más inmediatas: desde la búsqueda de nuevos mercados, hasta el desarrollo de infraestructuras capaces de reformar la ciudad y dar trabajo a una enorme población de obreros desempleados. A la postre, el objetivo último es la instauración de un adecuado contexto de relaciones económicas y comerciales con las repúblicas americanas, algo que ya se ensayó con los fastos conmemorativos del IV Centenario del Descubrimiento de América en $1892^{8}$.

Hemos de reconocer que la monstruosa gestación de la exposición hispalense se justifica en gran medida por la casi permanente irrupción de pequeños o grandes imponderables: problemas y tensiones locales de todo tipo, dificultades económicas casi irresolubles, la presentación de Bilbao - y de forma mucho más tímida la de Madrid- como ciudad candidata a celebrar una exposición similar, los conflictos que vive la política y la sociedad españolas durante el primer cuarto del siglo XX y, como gran colofón, la Primera Guerra Mundial. De hecho, si la inauguración se hubiera dilatado un poco más, la crisis económica internacional del mismo año de 1929 y, ya dentro de nuestras fronteras, la caída del general Primo de Rivera primero y la de la monarquía después, junto con las dificultades a las que se vio abocada la Segunda República y, por fin, el golpe militar y el estallido de la guerra civil en 1936, habrían imposibilitado la celebración de cualquier evento de la categoría y la complejidad de una exposición internacional.

Los veinte años que transcurren entre las primeras propuestas y la inauguración de la exposición no deben hacernos concluir que la presencia en el certamen de los pabellones coloniales se debe a un diseño igualmente tardío, originado durante la dictadura primorriverista, ya que dicha participación se menciona en el inicial proyecto que presenta públicamente el oficial del Ejército Luis Rodríguez Caso en junio de 1909. Precisamente el año de 1909 es una fecha clave, y especialmente trágica, en el proceso de expansión colonial de España en Marruecos, una fecha marcada por el desastre del 27 de julio en el Barranco del Lobo y por el fin de la denominada "penetración pacífica», sangría que da origen a una fuerte reacción anticolonialista en la Península y a los

\footnotetext{
${ }^{8}$ Se organiza entonces un amplio despliegue de exposiciones internacionales, celebradas durante los últimos meses de 1892 y los primeros de 1893; las dos más destacadas son la Exposición Histórico-Americana y la Exposición Histórico-Europea. Pese a que existe alguna bibliografía que estudia el IV Centenario, todavía no se han analizado a fondo las citadas exposiciones, aunque se puede encontrar información general en BernabeU AlBerT, Salvador: 1892: el IV Centenario del Descubrimiento de América en España. Coyuntura y conmemoraciones, Madrid, Consejo Superior de Investigaciones Científicas, 1987.

9 Solano, Op. cit, pp. 165-166. Rodríguez Caso presenta su propuesta durante el acto público en el que es condecorado por su protagonismo en la organización del evento denominado «España en Sevilla», que había sido organizado por el ayuntamiento sevillano en 1908 en conmemoración del centenario de la Guerra de la Independencia.
} 
acontecimientos de la Semana Trágica de Barcelona. De todas formas, no parece que exista relación alguna entre la intensificación de la presión militar en Marruecos a raíz de ese desastre y la propuesta de la presencia de esos territorios en una exposición internacional, ya que ésta se proyecta un mes antes de tan dramáticos sucesos. En realidad, el recrudecimiento de las campañas militares y de la resistencia rifeña en Marruecos inciden negativamente en la propia gestión del certamen.

Dejemos momentáneamente a un lado la política colonial de España en Marruecos y la conveniencia o no de presentarla a través de una exposición internacional, algo sobre lo que luego volveremos, y detengámonos en el porqué de la opción sevillana. Habría sido perfectamente factible que la proyección colonial de España se hubiera materializado en la exposición de Barcelona, de verdadero alcance y nivel internacionales, como hasta entonces habían hecho -y continuarían haciéndolo años después - las potencias europeas en todas las exposiciones universales o internacionales. Es más, Barcelona habría sido en realidad el mejor escaparate para «vender» y reivindicar, frente a las potencias coloniales europeas, la presencia colonial de España en África. Y este despliegue expositivo no habría resultado en modo alguno contradictorio con la orientación marcadamente tecnológica e industrial del certamen catalán, que tuvo a la electricidad y en concreto a la iluminación eléctrica como auténtico estandarte. Entonces, ¿por qué en Sevilla?

En primer lugar, Barcelona parece haber optado desde el primer momento por la organización de una exposición internacional, no exclusivamente iberoamericana. Al margen de esto, el mantenimiento y la consolidación de la opción americanista sevillana se fundamenta, al menos parcialmente, en la "primacía de la ideología» sobre la economía, algo que se puede rastrear en otros ámbitos del colonialismo español, aunque en modo alguno sea su único o principal rasgo estructural. Es cierto, como nos recuerda Martín Corrales, que «se admite con demasiada despreocupación que el colonialismo español en el noroeste de África se produjo como respuesta a la pérdida en 1898 de las colonias de Cuba, Puerto Rico y Filipinas», algo que sólo sería «una parte de la verdad» ${ }^{10}$. Pero también parece serlo el hecho de que tras el 98 se documenta en destacados ámbitos políticos e intelectuales - relacionados directa o indirectamente con el hecho colonial - cierto afán por recrear o reconstruir un nuevo imperio que, aunque africano, no rompa sus vínculos «espirituales» con la antigua idea y la antigua imagen del imperio ultramarino español. Surgiría así una especie de «hispanismo africano-americano», como se recoge en algún texto colonial de mediados de los años veinte, que incluso conectaría con las supuestas veleidades «africanistas» de nada menos que Isabel la Católica. Por supuesto, ese deseo de vincular - y nos

10 Martín CORRales, Eloy: «El protectorado español en Marruecos (1912-1956). Una perspectiva histórica» en J. Nogué y J. L. Vilanova (eds.): España en Marruecos (1912-1956). Discursos geográficos e intervención territorial, Lleida, Editorial Milenio (1999) pp. 143-158 (p. 145). 
referimos ahora al contexto expositivo- la política colonial de España en África con las relaciones internacionales entre el Reino de España y las repúblicas hispanoamericanas no deja de resultar chocante, contradictorio e incluso extemporáneo, ya que ambos procesos habrían de encauzarse en buena lógica por derroteros no sólo muy diferentes sino decididamente antagónicos.

Podemos comprender mejor las bases ideológicas de ese proyecto de conjunción entre lo hispano-africano (un entorno colonial) y lo hispano-americano (ámbito postcolonial supuestamente cohesionado en torno al concepto de Hispanidad) si nos acercamos a las más esencialistas justificaciones contemporáneas de la presencia española en África. En primer lugar, es bien conocido que la pobreza del territorio rifeño y la escasa rentabilidad económica de la presencia hispana en Marruecos, tanto antes como después del establecimiento del protectorado en 1912, condujeron a que «los publicistas africanistas se aferrar[a]n a una visión que sugería que a España no le movían intereses materiales sino que su labor en Marruecos era puramente espiritual, en vista de la cercanía histórica entre ambos pueblos, que habría forjado una comunidad de sangre hispano-marroquí» ${ }^{11}$. Esta presunta fraternidad histórica y espiritual hispano-marroquí sólo tenía una lacra: la renuncia expresa por parte de España a la cristianización de la población norteafricana. Quizás como compensación a tan dramática opción, España asume un nuevo compromiso y un nuevo reto espiritual en sus territorios del África ecuatorial: la muy cristiana empresa de convertir a la «desvalida» y «atrasada» población nativa de Guinea. La conjunción de ambos diseños de colonización da como resultado la articulación de un ingente proyecto de comunidad espiritual hispano-africana, muy cercano, al menos en teoría, al que en el pasado se había proyectado sobre las tierras americanas. Éstas son las bases ideológicas y espirituales que hacen posible que la exposición sevillana estructure sus contenidos en un modelo trinitario sustentado en la presencia de las provincias españolas, las repúblicas americanas ${ }^{12}$ y

${ }^{11}$ Mateo Dieste, Josep Lluís: La «hermandad» hispano-marroquí. Politica y religión bajo el Protectorado español en Marruecos (1912-1956), Barcelona, Edicions Bellaterra, 2003, pp. 28-29. Este mismo autor compara los modelos de «explicación esencialista» articulados por franceses y españoles para justificar su derecho a mantener las colonias: «desde Francia se destacaba una universalidad republicana que aglutinaba a sus pueblos colonizados y desde España se insistía en su capacidad de unir a los pueblos sobre la base de una misión universal de carácter espiritual» (p. 452).

12 Por obvias razones de política internacional, no participan en la exposición antiguas posesiones españolas que se han convertido en territorios coloniales de otras potencias. Los casos más destacados son los de Puerto Rico y Filipinas. En relación con todo esto, Assassin asegura que el certamen sevillano de 1929 es la única exposición «neocolonial» de la que tiene noticia, pues es la primera vez en la que «un pays invite la totalité de ses anciennes colonies, devenues états-nations, à se représenter, à venir mettre en valeur tous les progrès accomplis depuis leur indépendence» (Assassin, Sylvie: Séville: L’Exposition ibéro-américaine, 1929-1930, París, Institut Français d'Architecture, Norma, 1992, p. 69). Es ésta una cuestión discutible. En primer lugar, porque la Exposición Histórico-Americana de 1892 tendría ya ese supuesto carácter neocolonial, y en segundo, y más importante, porque no queda muy claro en qué consiste tal caracterización. 
las colonias hispanas de África, con el ineludible complemento de la presencia de varios pabellones institucionales y la participación de algunas empresas españolas y extranjeras. ${ }^{13}$ También debieron de tener su parte en el diseño de este «entramado espiritual» la cercanía geográfica de Sevilla al norte de África y los más o menos estrechos contactos de Andalucía con esas tierras allende el Estrecho. Aunque adelantemos conclusiones, es evidente que un modelo expositivo así no podía alcanzar el éxito que se había deseado, ni en lo que se refiere al desarrollo general de la exposición, ni en el ámbito específico de la muestra colonial ${ }^{14}$. El hecho de que se celebren dos exposiciones internacionales en un mismo país, de que ambas se desarrollen de forma simultánea y de que la otra ciudad sea precisamente Barcelona, no puede tener sino unas consecuencias claramente negativas para el diseño menos decididamente internacional y más anclado en la retórica de la Hispanidad, y este modelo no es otro que el sevillano ${ }^{15}$.

Retomemos ahora el segundo interrogante que planteábamos párrafos atrás, el relativo a por qué se recurre al formato expositivo para «dar a conocer» los territorios coloniales de España en África. La exhibición en Europa de individuos y, más adelante, de comunidades calificadas como «salvajes» o "primitivas» se documenta ya desde época renacentista, aunque lo cierto es que este tipo de acto o espectáculo se realiza entonces de forma muy episódica y circunstancial. Pero lo que ahora nos interesa es contextualizar adecuadamente la exhibición colonial de 1929, situándola en el ámbito de las exhibiciones etnográfico-coloniales especializadas - y oficiales — de la segunda mitad del XIX y las primeras décadas del XX, y más concretamente en el de las secciones igualmente coloniales de las exposiciones internacionales y universales contemporáneas. Afortunadamente, la bibliografía disponible sobre este tipo de eventos es ya muy abundante, y nosotros mismos hemos redactado una breve sínte-

13 Oficialmente, el certamen acoge doce «exposiciones» diferenciadas: arte antiguo, arte moderno, historia de la colonización española en América, regiones españolas, exposición histórica de Sevilla, industrias generales, agricultura, industria española, exposición colonial, exposición del libro, exposición nacional de turismo y exposición de América y Portugal. Se celebran, además, concursos y exposiciones de ganadería, varios congresos y competiciones deportivas. También se podía disfrutar de un parque de atracciones.

${ }^{14} \mathrm{La}$ afirmación que acabamos de hacer no es obstáculo para reconocer que la exposición sevillana contribuye de forma positiva al desarrollo urbanístico de la ciudad, pese a que en este ámbito se producen también algunas dificultades y contratiempos.

15 El acontecimiento más llamativo y singular de esa retórica de la Hispanidad es sin duda la «Cabalgata Histórica de la Raza Hispano-Americana» celebrada durante el certamen. El cortejo incluye la presencia de carrozas alegóricas y de un elevado número de figurantes que representan tanto a personajes como a tipos históricos significativos. Tras varios heraldos y un estandarte, encabezan la marcha un celta, un celtíbero y un ibero; la cierran un sacerdote «a caballo, [con] estola y un gran cartel que dice 'Unión por la iglesia'» y, tras él, una carroza con la «Madre» España, rodeada de veinte niñas que representan a las veinte naciones hispanoamericanas. Véase Cabalgata Histórica de la Raza Hispano-Americana. Organizada por el Comité de la Exposición, Sevilla, Imp. de la E[xposición] I[bero] A[mericana], Sección del Libro, 1929. 
sis en otro lugar con el objeto de poder explicar adecuadamente el alcance y significados de la Exposición de Filipinas celebrada en Madrid en 188716. Es bien conocido que tanto los países organizadores como los invitados recurren desde el primer momento a la exhibición pública de su dimensión colonial en estas ferias universales. Sin embargo, en las tres primeras grandes exposiciones - Londres, 1851 y 1862; París, 1855 - el modelo expositivo es muy simple y totalmente estático, limitado a la muestra de objetos y productos. En París, en 1867, se levantan por vez primera los a partir de entonces famosos pabellones nacionales, y también se construyen aquel año algunas instalaciones coloniales con bazares y puestos de artesanía. Pero hemos de reconocer que no nos encontramos aún ante las exhibiciones etnológicas coloniales propiamente dichas que veremos en certámenes universales posteriores, pues los personajes que aparecen en ésta y en la siguiente exposición parisina, la de 1878, participan «teóricamente» como responsables de la venta de productos exóticos en los muy populares restaurantes étnicos o desarrollan, de forma más o menos evidente y necesaria, alguna que otra actividad lúdica o artesanal. Es en 1883, en una exposición universal de rango menor - la Exposición Colonial de Ámsterdam- donde nos encontramos con la que quizás sea la primera exhibición colonial viva, que incluye no sólo la presencia de objetos y manufacturas exóticas, sino la completa reconstrucción de un poblado nativo y la presencia de individuos traídos expresamente para la ocasión, cuyo cometido principal no es otro que el de su mera exhibición.

Durante las dos últimas décadas del siglo XIX las secciones coloniales de las exposiciones universales crecen de forma exponencial, reforzando el modelo social-darwinista de dominación sobre el que se sustenta la expansión territorial, política, económica y cultural de Occidente. Las correspondientes a las exposiciones de París, en 1889 y 1900, y Chicago, en 1893, son sin duda las más conocidas y espectaculares. Entrada ya la siguiente centuria, los años previos al terrible parón expositivo que impone en Europa el estallido de la entonces conocida como Gran Guerra no son precisamente los que acogen la celebración de las más destacadas exposiciones internacionales o universales de la historia, y tampoco son especialmente significativas sus secciones coloniales, aunque es cierto que las celebradas en Bélgica — sobre todo la de Bruselas de 1910 - cuentan con extensas y dramáticas parcelas coloniales. Durante esos años, son los Estados Unidos los encargados de organizar las más espectaculares muestras internacionales y también coloniales, entre las que destacan la mastodóntica exposición de San Luis de 1904 y la de San Francisco de 1915 ${ }^{17}$.

16 SÁNCHEZ Gómez, Luis Ángel: «Las exhibiciones etnológicas y coloniales decimonónicas y la Exposición de Filipinas de 1887» en Revista de Dialectología y Tradiciones Populares (Madrid) LVII-2 (2002) pp. 79-104.

17 En la exposición de San Luis se organiza una exhibición filipina de enormes dimensiones que hemos estudiado en otro lugar (cf. SÁNCHEZ GómEZ: Un imperio, pp. 319-349). 
El fin de la Primera Guerra Mundial y la inicial expansión económica de los «felices años veinte» — terribles, en realidad, para gran parte de la población europea y americana que supuestamente los disfrutó- hacen posible que las potencias coloniales encaminen sus esfuerzos hacia la consolidación y modernización de sus posesiones ultramarinas. Soplan vientos de cambio, aunque no sean muy intensos, y la mayor parte de las metrópolis pretende ofrecer una imagen renovada de sus colonias, menos «salvaje» que en épocas anteriores. Se muestran habitadas por una población igual de exótica que en etapas precedentes, es cierto, pero ahora se argumenta de forma generalizada que algunas de esas gentes son capaces de adentrarse en los rudimentos de la civilización. En esta coyuntura histórica, las décadas de 1920 y 1930 contemplan una verdadera eclosión de exposiciones nacionales, internacionales y universales, muchas de ellas dedicadas en exclusiva al ámbito colonial. Entre las de orientación general, de nuevo organiza Bruselas un certamen universal, en 1935, y también en esta ocasión se recrean con intensidad y dramatismo sus territorios coloniales congoleños. Pero, como decimos, aquéllos son años de auténtica especialización expositiva colonial. En Europa, y al margen de otras de menor entidad, se organizan exposiciones coloniales nacionales en Marsella (1922), Wembley (192425), Turín (1928), Oporto (1934) y Glasgow (1938); finalmente, y en un contexto colonial internacional, se celebra en 1930 la Exposition Internationale Coloniale Maritime et d'Art Flamand de Amberes y en 1931 tiene lugar la famosa Exposition Coloniale Internationale et des Pays d'Outre Mer de París ${ }^{18}$.

Por la información hasta ahora disponible, podemos asegurar que España no está presente en ninguna de las secciones coloniales de las exposiciones internacionales que se organizan durante el primer tercio del siglo ${ }^{19} \mathrm{y}$, al margen del episodio sevillano de 1929, ningún gobierno español se decide a organizar un certamen colonial especializado dentro de nuestras fronteras después de 1887. Llama poderosamente la atención que el gobierno español rechace la invitación oficial para participar en el «gran acontecimiento» que vive París en 1931 con su exposición colonial, a la que sí acude, y parece que con notable «éxito», el vecino Portugal. Esta ausencia de España no es algo casual ni tampoco consecuencia de la más o menos tradicional desidia de la administración española; de hecho, tiene mucho que ver con el contexto colonial y con el propio modelo de exhibición que se estaba diseñando para Sevilla. Conviene detenernos un momento en este episodio.

En principio, no disponemos de ninguna información expresa que pruebe que la ausencia de España en el certamen de 1931 se deba a los problemas militares existentes en un Rif ya casi plenamente pacificado, o a los encontronazos

${ }^{18} \mathrm{La}$ referencia a los «países de ultramar» en la denominación oficial del certamen responde a una exigencia de los Estados Unidos, que sólo aceptan participar si se introduce esa expresa indicación, pues argumentan que sus territorios de ultramar no son propiamente «colonias».

19 Está documentado que hubo presencia oficial española en la exposición de Amberes de 1930 , pero no tenemos noticia de que se participara en la sección colonial. 
habidos con Francia por —entre otros contenciosos - la administración de Tánger, dejada prácticamente en manos galas desde 1923. Por otra parte, esas tensiones no fueron obstáculo para la colaboración puntual, tanto política como militar, entre ambos países, de la que obtuvo ciertos réditos la administración española. Aunque Primo de Rivera se ve forzado a abandonar el poder el 28 de enero de 1930 y fallece pocas semanas después, la organización del certamen galo se pone en marcha en 1926, lo que significa que el gobierno español recibe la invitación oficial después del desembarco de Alhucemas, cuando queda poco para doblegar de manera definitiva la resistencia bélica de los marroquíes en el protectorado. Es cierto que en aquel momento todavía no han concluido por completo las campañas militares, lo que podría ser un buen motivo para rechazar la invitación, pero también lo es que podrían haberse aprovechado las tareas, ya entonces muy adelantadas, relacionadas con la organización de la sección colonial en Sevilla, y reconducir todo ello para su presentación en París, en 1931. Podríamos pensar que no se dispone de energía suficiente para duplicar el esfuerzo; sin embargo, lo más probable es que el gobierno español recele de su participación en el certamen francés, asumiendo que los resultados no habrían de ser provechosos para la política colonial española, entre otras razones por la situación de debilidad de la política internacional de España. Aunque no parecen conocer cuáles son los territorios españoles en África, es muy posible que estén en lo cierto Hodeir y Pierre cuando afirman que la razón de la ausencia es bien simple: «le géneral Primo de Rivera ne souhaite guère investir dans un pavillon qui ne pourrait présenter qu'un empire colonial réduit au Rio de Oro...» ${ }^{20}$. De hecho, el antiguo imperio colonial español había quedado reducido a unos minúsculos territorios insulares y continentales en el África ecuatorial, además de a un protectorado marroquí de segunda fila, poco rentable ${ }^{21}$, escasamente poblado, extendido sobre unas tierras casi desérticas y claramente subordinado a los intereses y las ambiciones africanistas de Francia ${ }^{22}$. Mostrar una situación así, y hacerlo precisamente en la capital francesa, no parece que fuera especialmente apetecible. Esas posesiones podían y debían exhibirse en la propia España, para satisfacer la demanda interior de nuevos proyectos de futuro, para intentar superar antiguas frustraciones y reivindicar así la grandeza del nuevo régimen político. Además, quizás también tenga razón Assassin cuando asegura que la ausencia española en el evento de 1931 se debe a que España «ne désirait pas compromettre l'américanisme amplifié à la faveur de l'Exposition ibéro-americaine»23. De hecho, el gobierno tenía puestas muchas más expectativas en la potenciación de los vínculos culturales, políticos y sobre todo eco-

${ }^{20}$ Hoderr, Catherine; Pierre, Michel: 1931. La memorie du siècle. L'Exposition Coloniale, Bruselas, Éditions Complexe, 1991, p. 68.

${ }^{21}$ Pese a las expectativas puestas durante algunos años en las explotaciones mineras.

22 Aunque no fueron exhibidos en Sevilla debido a la débil presencia hispana o a su no efectiva ocupación, hemos de recordar que en 1929 España mantiene o reivindica su dominio sobre otros territorios africanos: la región de Ifni y lo que más adelante se conocerá como el Sahara Occidental.

${ }_{23}$ Assassin, Sylvie: Op. cit., p. 70. 
nómicos con las repúblicas hispanoamericanas que en la más que discutible rentabilidad de un colonialismo africanista condicionado y limitado por múltiples circunstancias.

En todo caso, si los gobiernos de España no quieren o no pueden arriesgarse a participar en una exposición colonial internacional, sí asumen que puede tener alguna utilidad la organización de un certamen doméstico que, como hemos anotado, está mucho más interesado en atraer la atención de la opinión pública nacional que la de las grandes potencias coloniales contemporáneas. Pero antes de adentrarnos en interpretaciones, hemos de insistir en que el recurso expositivo se considera en los años veinte como el cauce más destacado para dar a conocer a un público amplio, nacional e internacional, determinados proyectos, ideas o iniciativas. La celebración de la exposición sevillana y la organización de su sección colonial no hacen sino responder a la inercia de los tiempos.

Hemos tratado de explicar las razones que motivan la presencia de una sección colonial en la exposición de Sevilla - y no en la de Barcelona- e igualmente se han ofrecido algunas claves que permiten valorar el lugar ocupado por ese certamen en el enfebrecido ambiente expositivo que se vive en la Europa de entreguerras. ${ }^{24}$ Ahora es conveniente que dirijamos nuestra atención hacia la política y la práctica colonial españolas de la década de 1920, más concretamente a la nueva etapa que se abre a partir de 1923, tras el golpe militar del general Primo de Rivera.

El acceso al poder del marqués de Estella en septiembre de 1923 y la instauración de un régimen dictatorial — consentido o incluso auspiciado por Alfonso XIII - marcan el inicio de una nueva etapa en la política española y, en el ámbito que ahora nos interesa, determinan el punto de arranque para la organización definitiva de la exposición sevillana. Por la información disponible, parece quedar demostrado que Primo de Rivera tiene un interés especial en la celebración de ese certamen ${ }^{25}$. Es tal el impulso que toman los trabajos a partir de noviembre de aquel año, tras una entrevista mantenida por representantes del comité organizador con el dictador, que incluso se fija ya como fecha de apertura el 17 de abril de $1927^{26}$. Sin duda, Primo de Rivera ve con buenos ojos que España muestre a sus propias gentes y al resto del mundo los presuntos avances logrados por la sociedad española durante ese primer cuarto del siglo XX, muy espe-

${ }^{24}$ Queda sin plantear una cuestión que quizás pudiera tener algún interés: la comparación entre el contexto colonial de la exposición sevillana y las citadas exposiciones coloniales francesas de las décadas de 1920 y 1930, sobre todo teniendo en cuenta que España se inspira en el modelo francés para la articulación de ciertos mecanismos de gestión en sus posesiones africanas, especialmente en Marruecos. No obstante, la amplitud del fenómeno expositivo colonial francés es de tales dimensiones que obligaría a una investigación larga y pormenorizada. Además, probablemente el esfuerzo no merezca demasiado la pena, teniendo en cuenta lo muy limitado del registro expositivo español, que se reduce a dos únicos pabellones en una única exposición.

25 Cf. Solano: Op. cit.

${ }_{26}$ Finalmente, la exposición sevillana se inaugura de forma oficial el 9 de mayo de 1929, siendo su clausura el 21 de junio de 1930. 
cialmente tras la instauración del nuevo régimen político. Pero en ese ambiente de relativa euforia nacionalista, quizás el principal problema que aún no ha sido resuelto, tras casi tres años de gobierno, es precisamente el colonial. Es muy probable, por tanto, que el ya definitivo impulso que se da a la organización de la exposición sevillana a partir del 10 de marzo de 1926 - mediante un Real decreto que sitúa directamente bajo la Presidencia del Gobierno el control del Comité y la Comisión Permanente de la exposición- esté relacionado con el principio del fin de la pacificación del protectorado marroquí, que hace posible afrontar la política colonial en el norte de África desde una situación bastante más relajada, desconocida desde mucho tiempo atrás ${ }^{27}$. Es significativo que sea precisamente en junio de 1926 cuando el gobierno, quizás personalmente el dictador, se decida a vincular de una vez por todas los dos proyectos expositivos, como ya hemos adelantado. Es cierto que la orientación decididamente tecnológica e industrial del certamen barcelonés, que tiene también algunos resabios tradicionalistas, habría hecho posible su puesta en marcha al margen de los conflictos coloniales, pero teniendo en cuenta lo avanzado de ambos proyectos lo mejor era que las dos ciudades quedaran vinculadas y que sus certámenes aparecieran como complementarios, evitando así que se mostraran como dos iniciativas no sólo autónomas, sino incluso independientes.

\section{LA EXHIBICIÓN MARROQUÍ}

Alberto Darias, en su interesante artículo sobre la presencia de Marruecos en la exposición sevillana, señala que la participación marroquí en el certamen «se produce cuando se amplía el ámbito estrictamente hispanoamericano, al invitarse a Brasil, Portugal y Estados Unidos» ${ }^{28}$, lo que ocurre en noviembre 1922. Sin embargo, como hemos adelantado, la presencia de Marruecos había sido prevista ya en los primeros diseños expositivos de 1909, al igual que la de los territorios españoles del golfo de Guinea. Lo que sí podemos aceptar es la indicación hecha por el mismo autor de que esa participación es impulsada por el general José Sanjurjo — que está al frente de la Alta Comisaría del Protectorado entre 1925 y 1928 - y más aún por el militar conde de Jordana ${ }^{29}$, primero en su cargo como Director General de Marruecos y Colonias y más tarde como sucesor del propio Sanjurjo. El autor que venimos citando asegura que dicha presencia es «la consecuencia de una ideología regeneracionista que se había elaborado en el propio Marruecos a costa de los fracasos militares que

${ }^{27}$ Las campañas militares concluyen oficialmente en julio de 1927 , momento en el que se consigue la ocupación efectiva y total del territorio del protectorado, aunque todavía en 1928 tienen lugar algunas acciones de armas.

28 DARIAS PRÍNCIPE, Alberto: «La presencia de Marruecos en la Exposición Iberoamericana de Sevilla: razones de un resurgimiento manipulado» en Boletín de Arte (Málaga) 19 (1998) pp. 231-243 (p. 231).

29 Rafael Gómez-Jordana Prats, conde de Jordana, era hijo de Francisco Gómez-Jordana Sousa, que fue Alto Comisario del Protectorado en Marruecos. 
produjo la política indecisa de los diferentes gobiernos de Madrid» $»^{30}$, afirmación que responde en buena medida a la realidad pero que habremos de matizar. Sí parece quedar demostrado que el diseño más o menos definitivo de esa participación marroquí no comienza a perfilarse hasta cinco años antes de la apertura de la exposición, y es precisamente la preeminencia de lo militar el factor que en buena media orienta el modelo de exhibición, aunque no podemos desdeñar otros contextos civiles y religiosos - relativamente autónomos del control militar- que también tienen algo que decir en el evento.

\section{El pabellón oficial y los proyectos de promoción turística del protec- torado}

Centrándonos ya en el desarrollo de la exhibición, conviene destacar que la participación de Marruecos se concibe y estructura de un modo muy diferente al que se adopta para la presentación de los territorios del África ecuatorial; la extensa y compleja presencia de España en la zona lo hace inevitable. La orientación pseudo-etnográfica e incluso «salvajística» de la sección guineana está casi completamente ausente de la marroquí, aunque esto no es obstáculo para que se opte en determinados contextos por recrear de modo marcadamente exotista ciertas claves culturales de una presunta «esencia» alauita. Dando muestras de una cierta habilidad organizativa, la administración española se decanta por una doble y complementaria presentación del protectorado. De una parte, se levanta un vistoso y bien construido pabellón oficial que acoge la exposición colonial propiamente dicha, en el que se incluye una pequeña sección comercial y de esparcimiento. De otra, la iniciativa privada no desaprovecha la oportunidad de negocio que ofrecen tanto el certamen como el exotismo de lo marroquí y consigue que se apruebe la construcción de un «Barrio Moro», que se erige en una zona alejada del pabellón oficial para evitar que el visitante confunda las iniciativas oficiales con el negocio privado.

Aunque disponemos de dos trabajos en los que se ofrece alguna información sobre la presencia de Marruecos en la exposición —el citado de Darias y otro de Bellido ${ }^{31}$ - , en realidad apenas conocemos nada sobre el proceso de diseño y puesta en práctica de esa participación. Darias proporciona algunos datos sobre los orígenes y contenidos del pabellón oficial —obtenidos en parte

30 DARIas PrínCiPe, Alberto: Op. cit., p. 231.

31 Bellido GANT, María Luisa: «Promoción turística y configuración de la imagen de Marruecos durante el Protectorado español» en Cuadernos de Arte de la Universidad de Granada 33 (2002) pp. 221-234. Un artículo más compara los modelos expositivos sevillanos de 1929 y 1992: GRISTWOOD, Anthony: «Commemorating empire in twentieth-century Seville» en F. Driver y D. Gilbert (eds.), Imperial cities: landscape, display and identity. Manchester, Nueva York, Manchester University Press (1999) pp. 155-173. Sin embargo, su análisis de la exhibición colonial no aporta novedades sustanciales. 
de la memoria oficial que se conserva en el Archivo General de la Administración, en Alcalá de Henares ${ }^{32}$-, pero se trata de una información elaborada expresamente para dejar constancia del esfuerzo y de las patrióticas intenciones de sus redactores, lo que limita notablemente su utilidad historiográfica. En dicha memoria se asegura que el diseño arquitectónico del pabellón había sido perfilado años antes de la exposición, sin que sus creadores hubieran considerado seriamente que pudiera tener alguna utilidad práctica en el futuro. Habría sido el fruto, según Darias, de un mero «divertimento», aceptando así la explicación propuesta en la memoria oficial por quienes fueron los autores del proyecto: el arquitecto José Gutiérrez Lescura y el pintor Mariano Bertuchi33. Ambos se refieren exclusivamente al diseño arquitectónico del edificio, pero aun así no podemos confirmar que su origen fueran tan simple como el que ellos mismos argumentan en dicha memoria: «obligados, por razón de sus cargos y de sus aficiones, a permanecer en la zona del Protectorado Español en Marruecos, enamorados del Arte Árabe, peculiar de ésta, concibieron la idea de redactar un Anteproyecto de Pabellón Marroquí en una Exposición» ${ }^{34}$. En todo caso, es obvio que la presencia de Marruecos en Sevilla responde a circunstancias más complejas y no tan marcadamente personalistas.

De los dos personajes responsables del diseño del pabellón oficial, parece claro que es Bertuchi quien «marc[a] el ideario político y cultural» de la construcción ${ }^{35}$. Hacia el exterior, el pabellón combina la imagen de una residencia marroquí de familia acomodada y la de una mezquita con un vistoso alminar y una atractiva cúpula; los accesos quedan enmarcados por arcos de herradura ligeramente apuntados, modelo que también se emplea en las puertas que comunican con el bello patio interior ${ }^{36}$. El autor que citamos ofrece una correcta descripción del edificio ${ }^{37}$ :

32 Memoria del Pabellón de Marruecos en la Exposición de Sevilla, AGA, caja 116, exp. 11.

33 Aunque otros artistas españoles recrean imágenes «orientalistas» de Marruecos desde finales del siglo XIX, Bertuchi (1885-1955) puede ser considerado el verdadero responsable de la iconografía oficial del protectorado, que se traslada incluso a los sellos de correos. Acerca de su amplio repertorio de dibujos y pinturas sobre las tierras y gentes marroquíes, puede consultarse el catálogo de la exposición Mariano Bertuchi, pintor de Marruecos, Barcelona, Lunwerg, 2000. También es recomendable el repaso de algún catálogo de sellos de las dependencias postales españolas.

${ }^{34}$ DARIAS PRÍNCIPE, Alberto: Op. cit., p. 231. La vinculación del diseño del pabellón con el modelo de arquitectura colonial que España desarrolla en Marruecos se puede constatar en un detallado y magníficamente editado libro de Antonio BRAVO NiETO: Arquitectura y urbanismo español en el Norte de Marruecos, Sevilla, Junta de Andalucía, Consejería de Obras Públicas y Transportes, 2000 (cf. esp. pp. 179-181).

35 Ibidem.

36 A diferencia de lo ocurrido con el pabellón de Guinea y del «Barrio Moro», el de Marruecos no fue derribado tras la clausura de la exposición, aunque sí desaparecieron algunos anexos. Actualmente es la sede del «Servicio de Parques y Jardines» del Ayuntamiento de Sevilla. Su dirección es Avenida de Moliní, 4.

37 DARias PRíncipe, Alberto: Op. cit., p. 234. Pese a todo, la más detallada descripción que conocemos del pabellón es la de FerNÁNDEZ, Santos: «Marruecos en la Exposición Ibero-Americana 
En la coloratura [sic] exterior del pabellón dominaba el blanco, a excepción de los tejadillos de las sobrepuertas, los arcos ciegos y el remate del minarete que se cubrían con azulejería verde. En el interior se ofrecía un variado cromatismo gracias a la policromía de los alicatados así como de las taraceas de armaduras y puertas.

El patio árabe, un cuadrado de 12 por 12 metros, resultaba el conjunto más rico; centrado por una fuente, daba paso a diferentes estancias: la principal, al fondo, constituía el llamado salón moro, recreación de la estancia noble de la casa de un notable de la zona. En flancos, se disponían dos habitaciones por lado; a la derecha, la sala de la colonización, donde se exponían productos agrícolas y mineros del país, y a su lado, la sala de arte, galería de pintura de artistas nacionales que dieron a conocer paisajes, tipos y motivos del Protectorado.

Adjunto al edificio, y con acceso independiente, figuraba lo que se denominó parque comercial marroquí. Allí se ubicó la zona más vital del pabellón: a un lado el bazar con el café y al otro la alcaicería. Todo ello, tal y como se da en la medina tetuaní, cubierto por un emparrado.

Según la memoria oficial del proyecto, se deseaba

[...] presentar no un edificio de exposición, frío y sin vida, sino una instalación que a la par que se ajuste en la medida de nuestro saber, al estilo de este país, lleve un poco de vida palpitante. A este efecto responden los bazares y el café moruno, y nuestro propósito de que los materiales característicos sean fabricados en Tetuán y colocados por obreros indígenas especializados. Creemos que así se obtendrá un edificio que al pasar por exótico en Sevilla, encajará muy bien en el ambiente, la luz y la tradición del pueblo sevillano ${ }^{38}$.

Los dos recursos expositivos que se mencionan en el párrafo trascrito - la sección comercial y la condición nativa, por tanto «original», de materiales constructivos esenciales y de obreros - habían sido utilizados desde las primeras muestras coloniales organizadas en Europa en las que se levantan edificios singulares, concretamente desde la Exposición Universal de París de 1867, como ya vimos. Lo que destaca del proyecto sevillano es la sobriedad y, al tiempo, el efectismo de la construcción, además de la calidad de los materiales. El diseño y la ejecución del edificio pueden considerarse un auténtico acierto,

de Sevilla» en Africa. Revista de Tropas Coloniales (Ceuta) 53 (mayo de 1929) pp. 111-115, artículo que se acompaña de ocho fotografías de gran calidad. Citamos el nombre de la revista sin la tilde, tal y como se recoge en su cabecera. Las publicaciones oficiales ofrecen muy escasa información sobre los contenidos de la exposición. Así, el tomo primero - el segundo nunca se editó- del voluminoso, lujoso y pesado Libro de Oro Ibero-Americano, subtitulado Catálogo oficial y monumental de la Exposición de Sevilla (Santander, Unión Ibero-Americana, [1929]), no es un catálogo del certamen, sino una especie de síntesis histórica, geográfica y comercial de las regiones de España, con treinta páginas dedicadas a Marruecos y únicamente cinco a la Guinea Española. La guía oficial, que más adelante se cita, sí ofrece alguna información, pero lo hace de forma extremadamente escueta.

38 Cf. Bellido Gant: «Promoción...», p. 229. 
no sólo en el contexto expositivo del momento, sino desde una perspectiva artística y arquitectónica.

El recurso de manera exclusiva a formas arquitectónicas y decorativas de origen marroquí es algo que quizás pudo provocar algunas suspicacias de corte nacionalista o incluso «racial» entre algunos visitantes o, peor aún, entre determinados personajes de las distintas administraciones implicadas en el evento. Santos Fernández, redactor de la revista militar Africa, parece ser consciente de esta circunstancia, a la que da una respuesta tan rotunda como evidente ${ }^{39}$ :

Alguien quizá pretendiera objetar lo servil de la imitación de obras arquitectónicas de nuestra zona. Pero esto, lejos de ser una objeción, es el mayor mérito del edificio. Se trataba de representar a Marruecos con arte marroquí. El haber dejado suelta a la imaginación hubiera sido haberse desviado del objetivo esencial. Se ha logrado recoger verdaderamente el alma de la arquitectura mora de nuestra zona.

Fuera de lo anotado, sabemos poco de los contenidos del pabellón, que vigilan cuatro soldados marroquíes con uniforme de Regulares. Sí disponemos del dato oficial de su superficie: 680 metros cuadrados construidos, sobre una parcela de 765, bastantes menos de los que ocupa el pabellón de Guinea, aunque en realidad este último cuenta con un gran espacio abierto destinado a los espectáculos nativos. Además del proyecto global de reivindicación de la presencia colonial - aún eminentemente militar - de España en África y de la exhibición pública de los presuntos beneficios y progresos logrados por la sociedad marroquí, el eje central sobre el que se articulan los contenidos del pabellón gira en torno a la potenciación de las industrias artesanales nativas: cerámica, alfombras, cuero repujado, marquetería, pintura decorativa, forja, etc., contexto en el que se venía trabajando desde algunos años antes, al parecer con éxito, a través de la Escuela de Artes Indígenas de Tetuán, a cuyo frente estuvieron los dos responsables del diseño del pabellón: Gutiérrez Lescura, entre 1921 y 1930, y Bertuchi, a partir de ese año ${ }^{40}$. Conocemos también que buena parte de los objetos marroquíes expuestos en el pabellón pertenecen al Museo de Artes Indígenas y a la citada Escuela de Tetuán, mostrándose asimismo piezas procedentes de las colecciones reales españolas. En este sentido, Santos Fernández anota en su artículo sobre el pabellón que hubiera sido conveniente que sus contenidos no se limitaran a reflejar la historia y el arte de Marruecos, y que debería haberse dado cabida al «arte y la historia hispano-arábigos», para reforzar así los rasgos compartidos de una presunta identidad hispanomarroquíi ${ }^{41}$.

39 FERnÁndeZ, Santos: Op. cit., p. 112.

40 El primer director, entre 1919 y 1921, fue otro personaje vinculado con la exhibición colonial: el ingeniero y militar retirado Antonio Got Inchausti, quien tuvo a su cargo el diseño del «Barrio Moro».

41 FERnÁndeZ, Santos: Op. cit., p. 115. 
Junto con los proyectos de promoción política y artístico-comercial del protectorado, un tercero viene a conjugar la esencia de ambos en el modelo de participación marroquí en la exposición. Nos referimos al turismo. Y es que en la década de los veinte se viven años de auténtica euforia turística en Europa, que se proyecta también hacia algunos destinos exóticos no demasiado alejados del continente, sobre todo del norte de África. Aunque quizás no sea muy conocido, España se apunta en fecha temprana al fomento del turismo, tanto nacional como extranjero. De hecho, el primer organismo español de promoción turística se crea en 1905 con la denominación de "Comisión Nacional para fomentar las Excursiones Turísticas», y esto se hace antes de que aparezcan las primeras instituciones similares en Francia, Suiza o Italia ${ }^{42}$. En 1911 surge otra institución de mayor peso, la Comisaría Regia de Turismo, que se refunde en el Patronato Nacional de Turismo por Real decreto de 25 de abril de en 1928. Durante las dos primeras décadas de promoción oficial del turismo en España, las autoridades apenas son conscientes de la importancia económica del fenómeno. Los principales objetivos que entonces se buscan son la «divulgación histórico-artística de la riqueza monumental y artística española» ${ }^{43} \mathrm{y}$, sobre todo, proyectar hacia el exterior una imagen positiva del gobierno y del régimen político imperante en cada momento en el país. Una novedad importante asociada a la creación del Patronato en 1928 es que por vez primera se conceptúa el turismo como «fuente de riqueza», sin que por ello se olvide su papel como «fuente de prestigio nacional» ${ }^{44}$. Aunque la escuálida infraestructura de comunicaciones, transportes y alojamientos del país dificulta la expansión turística, lo cierto es que durante estos años finales de la década de 1920 y hasta la Guerra Civil la labor del Patronato es intensa y notable. En ese renovado contexto, la Dirección General de Marruecos y Colonias forma parte desde el primer momento del Consejo General del nuevo organismo, quedando incluido el protectorado en la «región turística» de Andalucía-Canarias.

Y, ¿cómo se vincula la creación del Patronato con las exposiciones de 1929? Pues, de forma muy directa. De hecho, el mismo preámbulo del Real decreto de 25 de abril explicita la necesidad de potenciar el turismo a través del nuevo organismo con el fin de aprovechar de forma inmediata el reclamo internacional que suponen las exposiciones de aquel año. Y sin duda es precisamente por la inmediatez de aquellos dos destacados eventos por lo que la iniciativa no queda reducida a un simple proyecto o a una declaración de intenciones, sino que se pone en marcha con notable vigor y con una base presupuestaria más o menos ajustada. Por todo ello, la relevancia político-cultural y, ya también, económica que se concede al turismo por parte de la adminis-

42 Cf. Esteve SeCall, Rafael; Fuentes García, Rafael: Economía, historia e instituciones del turismo en España, Madrid, Ediciones Pirámide, 2000, pp. 21-23.

43 Ibidem.

${ }_{44}$ Ibidem 
tración del Estado en aquel momento se refleja perfectamente en las exposiciones internacionales de Sevilla y Barcelona. Precisamente el mayor éxito de la exposición catalana lo obtiene, junto con las fuentes iluminadas de Montjuïc, el famoso Pueblo Español, cuyo objetivo no es otro que atraer el interés del turismo nacional e internacional mediante la reproducción de las más características, de las más «típicas» y «tradicionales» arquitecturas de los pueblos de España. Y por lo que respecta a Sevilla, no debemos olvidar que allí se organiza una Exposición Nacional de Turismo que alcanza un notable éxito de público; además, buena parte de los restantes contenidos del certamen tienen una eminente orientación turística, sobre todo las secciones dedicadas a las regiones españolas y a la Exposición Histórica de Sevilla. En este ambiente, no es de extrañar que uno de los objetivos del pabellón marroquí sea precisamente la promoción del turismo en el recién pacificado protectorado, aunque es cierto que la mayor parte del esfuerzo propagandístico se centra aún en el área de Tetuán ${ }^{45}$. Por ello, y pese a que no tenemos constancia expresa de su puesta en práctica, se proyectó que la Oficina de Turismo de la Dirección de Colonización del protectorado tuviera una representación en el pabellón marroquí, a la que se confiaría en exclusividad «la misión de evacuar cuantas consultas hagan sobre turismo a la Zona los concurrentes al magno certamen» ${ }^{46}$.

También el cine, sobre todo el de carácter documental, se utiliza como recurso de especial relevancia para propagar las bondades turísticas del protectorado y, por supuesto, para alabar las mejoras allí introducidas por la administración española durante la dictadura. Fernández Colorado hace referencia a diversas películas y documentales sobre los territorios norteafricanos que son exhibidos tanto en la Península como en el propio territorio marroquíi ${ }^{47}$; en este último caso, el propósito defendido por algún personaje de mentalidad colonial más decididamente «moderna» era que se convirtieran en «medio civilizador», aunque para ello hubiera que recurrir a filmes que presentaran «ideas simples y primitivas» y que se acercaran lo más posible a "sus costumbres [de los marroquíes] en contacto con la naturaleza», como argumenta un artículo periodístico de $1928^{48}$. Aunque desconocemos cuáles fueron las películas que se proyectaron durante el certamen hispalense, parece que la productora «Marruecos Films», de Luis Ricart y Jaime Mola, rodó al menos dos documentales —-siempre bajo supervisión militar- destinados expresamente para ser proyectados tanto

\footnotetext{
45 Cf. Bellido GanT: «Promoción...».

46 «Fomento del Turismo en la zona española de Protectorado Marroquí», en Africa. Revista de Tropas Coloniales 51 (marzo de 1929) p. 72.

47 FERnÁndeZ COlORADO, Luis: «Visiones imperiales: documental y propaganda en el cine español (1927-1930)» en Josetxo Cerdán y Julio Pérez Perucha (coords.), Tras el sueño: Actas del Centenario.(VI Congreso de la Asociación de la Asociación Española de Historiadores del Cine), Madrid, Academia de las Artes y las Ciencias Cinematográficas de España [monográfico de Cuadernos de la Academia, 2] (1998) pp. 97-110.
}

48 Ibidem: 107. 
en la exposición de Sevilla como en la de Barcelona. Sus títulos habrían sido Melilla y Larache. No obstante, por lo que hasta ahora se conoce de los contenidos de tales filmes, es muy probable que tenga razón A. Elena cuando afirma que la cinematografía colonial de estos años no parece concebirse sino como «un medio de abierta exaltación castrense», por lo que «resultaría difícil identificar en la producción española del período mudo algo equivalente a lo que, en una obra clásica, Pierre Leprohon bautizara como reportaje colonial $[\ldots . ..] »^{49}$.

\section{El «Barrio Moro»}

La construcción del «Barrio Moro» responde a la iniciativa privada, en concreto a la firma Olivencia y Compañía, de acuerdo a un proyecto elaborado por Manuel Olivencia Amor. El diseño artístico es obra del ingeniero, ex-militar y pintor Antonio Got, profesor de la Escuela de Artes Indígenas de Tetuán y, como vimos, su primer director, quien estuvo también al cargo de todo el personal marroquí empleado en las distintas instalaciones ${ }^{50}$. El recinto, al que se accede a través de una reproducción de la puerta de Tánger en Tetuán, nos es descrito con brevedad por la guía oficial ${ }^{51}$ :

El pabellón está dividido en tres parte. La primera, [...] la construyen $[$ sic $]$ los bakalitos o pequeñas tiendas morunas, formando un patio similar al del barrio de los babucheros de Tetuán. En la segunda se alza la mezquita, coronada por la famosa torre de Yemaal Bacha [Yama-al-Bacha], de forma octogonal. Entre las instalaciones que comprenden la tercera parte del pabellón, hay un gran café estilo marroquí, decorado ricamente con haitis ${ }^{52}$, colchonetas, cerámicas y armas del país, repisas y mesas de maderas morunas.

Debemos advertir, como se hace también con satisfacción en la revista Afri$c a$, que la mezquita del «Barrio Moro» acoge todas las instalaciones propias del culto, por lo que el minarete no se erige en calidad de mero símbolo artísticoarquitectónico. Y eso a pesar de que se trata en efecto de una referencia visual especialmente destacada, pues se eleva a la nada desdeñable altura de 26 me-

49 ELENA, Alberto: «Políticas cinematográficas coloniales: España, Francia y el Protectorado de Marruecos» en F. Rodríguez Mediano y H. de Felipe (eds), El Protectorado español en Marruecos. Gestión colonial e identidades, Madrid, CSIC (2002) pp. 13-35 (p. 19).

${ }^{50}$ Este último dato lo anota FernánDEZ, Santos: Op. cit., p. 113.

${ }^{51}$ Exposición Ibero-Americana. Sevilla (España) 1929-1930, Barcelona, Madrid, Sevilla, Negociado de Publicidad de la Exposición Ibero-Americana, Rudolf Mosse Ibérica, S. A., [1929], p 76. En cubierta: Sevilla. Exposición Iberoamericana 1929-1930. Guía oficial. En FERNÁNDEZ, Santos: Op. cit., se reproducen interesantes fotografías de esta instalación. En el número 56 de la misma revista, Africa, correspondiente al mes de julio, se ofrecen algunos otros datos complementarios y tres fotografías más.

52 «Haiti»: tapiz o colgadura. 
tros, según anota en su artículo Santos Fernández. Este mismo redactor informa sobre el doble significado y el doble objetivo que se pretende alcanzar con la puesta en marcha de esta sección comercial $^{53}$ :

Para dar noticia y comprender exactamente lo que este pabellón es, hay que examinarlo desde dos puntos de vista distintos: desde el punto de vista de los marroquíes y desde el punto de vista de los extranjeros. A todos se ha querido dar satisfacción. A los primeros, disponiendo que haya en el Barrio Moro todo cuanto de ordinario está acostumbrado a ver y a necesitar un marroquí en su tierra, y a los segundos procurando que no falte ningún rasgo sustancial para que la idea que se formen de Marruecos sea completa.

El «Barrio Moro» sevillano es un fiel heredero de la tradición ferial lúdicoexótica que había estado y continuaba estando presente en casi todas las exposiciones internacionales y universales, muy especialmente en las francesas. El objetivo primordial de la empresa es rentabilizar de forma inmediata la inversión, para lo cual resulta de enorme utilidad atraer la atención del público a través de la idealización arquitectónica y el reforzamiento del exotismo de los tipos humanos, de su indumentaria y de las tareas que desempeñan. Con sus instalaciones, y con las actividades que allí desarrollan sus exóticos trabajadores y artistas, no se pretende desarrollar ningún proyecto colonial concreto, pero es evidente que de forma implícita se generan y refuerzan las más tópicos imágenes sobre el exotismo «oriental» del norte de África, un territorio situado a tan solo hora y media de la península, como ya por entonces anuncia la propaganda turística oficial. La guía del certamen describe perfectamente ese abigarrado mundo de exóticas sensaciones que se ofrece al visitante y cliente:

[El «Barrio Moro» es] De una justeza exacta, con sus tiendas chiquitas y bajas de vivos colores, en las que el moro expone y vende sin recatarse de la visita [sic] del observador, babuchas, armas, joyas, faroles y objetos de cuero; donde tomaremos el renombrado té moruno en uno de sus cafetines; donde admiraremos sus típicas barberías, sus fondas donde alojarse y hacer sus comidas ${ }^{54}$.

Pero aunque hemos anotado que el «Barrio Moro» no parece ser el entorno más adecuado para el mensaje político directo, un contemporáneo al evento, concretamente un redactor de la Revista Hispano Africana, sí encuentra una motivación política en su construcción, "pues es indudable que este hecho nos traerá el afecto y la confianza del marroquí, que ha de sentirse halagado al ver que nos complacemos de su concurso en una Exposición internacional de pueblos hermanos» ${ }^{55}$. Considera, por tanto, que el exotista modelo de exhibición

53 FERNÁNDEZ, Santos: Op. cit., p. 113.

${ }_{54}$ Exposición Ibero-Americana. Sevilla (España), p. 75.

55 «El barrio moro en la Exposición iberoamericana de Sevilla», en Revista Hispano Africana (Madrid) 8-9 (agosto-septiembre de 1928), p. 13. 
de la sociedad marroquí diseñado por una empresa privada española ha de ser reconocido como suyo por parte de la población del protectorado, al menos por parte de sus estamentos sociales más representativos. Una argumentación tal sólo puede surgir de una mente profundamente inocente o, lo que es mucho más probable, decididamente cínica ${ }^{56}$.

\section{COLONIZACIÓN Y EXHIBICIÓN DE GUINEA}

Como ya se ha adelantado, y como tendremos oportunidad de analizar con detalle en el siguiente apartado, la exhibición guineana difiere sensiblemente de la marroquí. No podía ser de otra forma, dado que los modelos de ocupación, explotación y desarrollo articulados por los gobiernos de España en el norte de África y el golfo de Guinea habían circulado y circulaban aún por cauces claramente disímiles. No obstante, y a pesar de esas diferencias históricas y expositivas, es justo en los años inmediatamente anteriores a la celebración del certamen hispalense cuando se logra una ocupación casi definitiva y ya relativamente estable de ambos territorios, lo que de algún modo posibilita que la coincidencia espacio-temporal de esos dos contextos coloniales en la exposición se vea reforzada por un aparente proyecto compartido de consolidación de la presencia española en África.

En el caso de Guinea, esa ocupación efectiva, o casi, se consigue tras la expedición continental comandada por el general de brigada Miguel Núñez de Prado en 1926, que había sido nombrado gobernador general de los territorios españoles en el golfo ${ }^{57}$. Es bastante evidente que el proceso de ocupación colonial había sido lento, muy lento. Si es cierto que el establecimiento formal de la soberanía española sobre Fernando Poo, la actual Bioko, data de 1778, también lo es que la penetración continental apenas si se había producido en un momento tan avanzado como el año de 1900, fecha en la que se firma el famoso Tratado de París que fija los límites de los territorios españoles y franceses en el África ecuatorial. Además, hasta 1858 no se produce el establecimiento formal de una incipiente administración colonial en Fernando Poo, presencia

${ }^{56}$ En su informe sobre el presente artículo, uno de los evaluadores anónimos consultados por Hispania anota que esta afirmación puede no ser correcta. Es muy probable que tenga razón, y que en realidad el argumento del periodista que se cita no sea ni inocente —esto es obvio- ni totalmente cínico. Se trataría pues de una reflexión presuntamente sincera vinculada con los proyectos de modernización de la sociedad marroquí diseñados por la administración española. De todas formas, sigo considerando que el comentario está cargado de un cierto cinismo.

57 Núñez de Prado se mantuvo en el cargo hasta 1931. Testimonios periodísticos de la época aseguraban tras su nombramiento que la misión de este militar - y la del conde de Jornada al frente de la recién creada Dirección General de Marruecos y Colonias- era tan básica y esencial como la de «descubrir las colonias» (cf. F.-Fígares Romero DE LA CrUZ, María Dolores: La colonización del imaginario: imágenes de África, Granada, Universidad de Granada, 2003, p. 220). 
oficial a la que se suma un muy reducido contingente de misioneros, únicamente seis jesuitas, que son los primeros españoles que afrontan la labor de cristianizar a la población de Bioko. En realidad, esa labor de cristianización ya había sido comenzada por misioneros protestantes - y la continuarán desempeñando durante todo el periodo colonial_- pues no debemos olvidar que la isla de Fernando Poo es a mediados del siglo XIX una especie de colonia oficiosa británica — presencia y actividad expresamente autorizadas por el Reino de España- que cuenta con una población africana llegada o traída de muy diversos territorios del golfo de Guinea ${ }^{58}$.

La firma del Tratado de París, que tiene lugar 27 de junio de 1900, fija de forma definitiva los límites de las posesiones de España y Francia en el golfo de Guinea y deja en manos españolas una minúscula extensión de tierra africana en comparación con la que se reservan los franceses. Pese a tal descalabro -que, al parecer, conduce al suicidio del comisario regio encargado de reconocer los límites establecidos en el tratado_-, es a partir de entonces cuando da comienzo el lento proceso de ocupación colonial del territorio continental. Una de las primeras iniciativas puestas en práctica por los administradores españoles después de la firma del acuerdo es declarar oficialmente a los territorios del golfo de Guinea «colonias de explotación económica; considerando a sus distintas poblaciones como el instrumento prioritario para llevar a cabo tal explotación», lo que ocurre en $1904^{59}$. Da comienzo entonces la verdadera política indígena colonial, creándose ese mismo año el Patronato de Indígenas, cuyos objetivos son «proteger a los niños o indígenas» y «fomentar la cultura y moralización de los naturales del país y su adhesión a España». Como escribe Sánchez Molina ${ }^{60}$,

para que esta función tutelar pudiera llevarse a efecto, la legislación colonial reducía a todos los africanos de la colonia a la categoría de indígenas, siguiendo el patrón de las Leyes de Indias. Con el inicio de esta política indígena, el Patronato de Indígenas queda con la exclusiva competencia de otorgar la ciudadanía española a la población africana de los territorios, anulando la anterior normativa de 1888 que otorgaba este estatus a todos aquellos africanos bautizados.

Es obvio que la institución del Patronato cubre con un velo de paternalismo un fenomenal mecanismo de dominación, que se refuerza aún más con las reformas introducidas en 1928. La renovada legislación promulgada aquel año

58 Cf. Castro, Mariano L. de; Calle, M. Luisa: Origen de la colonización española en Guinea Ecuatorial (1777-1860), Valladolid, Universidad de Valladolid, 1992.

59 SÁNCHEZ MOLINA, Raúl: «Homo infantilis: asimilación y segregación en la política colonial española en Guinea Ecuatorial» en Revista de Dialectología y Tradiciones Populares (Madrid) LVII-2 (2002) pp. 105-120 (p. 108).

60 SÁnChez Molina: Op. cit. pp. 108-109. En el resto de su artículo, Sánchez Molina estudia los contextos de asimilación y racismo de la política franquista con respecto a la población guineana. 
«divide legalmente la población africana de los territorios, mediante categorías tomadas de la legislación esclavista de las ex-colonias antillanas, en noemancipados, y, por lo tanto, sometidos a la tutela del Patronato de Indígenas, y en emancipados que, con los mismos derechos que el resto de los españoles, podían quedar liberados del tutelaje de la institución» ${ }^{61}$. Aunque es a partir de la formulación de sus últimos estatutos, en 1938, cuando el Patronato alcanza su definitiva estructuración y es durante el franquismo cuando adquiere su máxima importancia, ya en esos años finales de la década de 1920 se han fijado las bases de la caracterización y definición colonial de la población nativa guineana.

Todas estas medidas afectan al conjunto de la colonia, pero su implantación en el territorio continental es mucho más lenta y complicada que en las islas. De hecho, la mayor parte de las incursiones que se realizan en el continente entre 1900 y 1926 - que se enfrentan a una no desdeñable resistencia nativa - tienen como objetivo primordial el reclutamiento, quizás sencillamente la captura, de braceros para su traslado a las plantaciones de Fernando Poo, preocupando mucho menos el afianzamiento real de esa presencia colonial ${ }^{62}$. La delimitación fronteriza del territorio continental que se consigue entre 1926 y 1927 contribuye a una relativa estabilización de la ocupación de estos territorios, labor que se ejerce bajo el control directo e inmediato de los militares. Pese a todo, las imágenes que de la colonia continúan llegando mayoritariamente a la península son las que muestran a los territorios guineanos como espacios salvajes e insalubres que, además, resultan un lastre para la economía del país. Las dificultades y la propia indefinición de las políticas gubernamentales son tales que el propio gobernador de la colonia, Núñez de Prado, llega a afirmar en mayo de 1930 que «el único problema es que España de una vez y en forma categórica decida si quiere colonias o no» ${ }^{63}$.

En resumen, es evidente que las trascendentales iniciativas militares y político-administrativas que se ponen en marcha en los territorios del golfo de Guinea entre 1926 y 1929 —unidas a una todavía incipiente explotación económica y a los debates sobre la escasez de braceros- justifican de manera sobrada la presencia de la colonia en la exposición sevillana ${ }^{64}$. Pero antes de aden-

${ }^{61}$ Ibidem: 109. Véase también NDONGO-Bidyogo, Donato: «Guineanos y españoles en la interacción colonial (1900-1968)» en M. de Castro y D. Ndongo, España en Guinea. Construcción del desencuentro: 1778-1968, [Madrid], Ediciones Sequitur (1998) pp. 107-217. Este autor presenta de forma detallada los mecanismos y los recursos legales con los que la administración española pretende dar forma a una sociedad colonial estable y adecuadamente supervisada a partir de 1900, y muy especialmente a partir de la década de 1920. No estudia, sin embargo, las formas de explotación económica desplegadas por españoles y otros europeos, y tampoco analiza con detalle el entramado de relaciones sociales, conflictivas o de cooperación, que se extiende durante ese periodo.

62 F.-Fígares Romero de la Cruz, María Dolores: Op. cit., p. 98.

63 Ibidem: p. 225.

${ }^{64}$ Que la explotación fuera incipiente no es obstáculo para que resultara muy rentable para las pocas empresas y colonos allí asentados, aunque lo era mucho menos para la hacienda española. Sobre este y otros interesantes temas escribe, desde una perspectiva crítica y en ocasiones 
trarnos en el estudio del certamen, merece la pena dedicar unas líneas al reflejo que tienen en la cinematografía contemporánea los significativos avances de la política colonial guineana. No tenemos constancia escrita que lo pruebe, pero es muy probable que durante la celebración del certamen se exhibiera en Sevilla alguno de los dos documentales cinematográficos rodados en Guinea en 1928, iniciativas ambas que son muestras especialmente destacadas de la intensa campaña de propaganda colonial que se pone en marcha durante el mandato de Núñez de Prado ${ }^{65}$. El primero en filmarse es el titulado En las márgenes del río Muni. Se rueda por iniciativa de Manuel Alonso García — capitán del Estado Mayory lo dirige Eduardo Prados ${ }^{66}$. A finales de ese mismo año, Facundo Godoy rueda Expedición a Guinea Ecuatorial, que tiene una duración muy respetable: 47 minutos. Se realiza este último documental con motivo del viaje a la colonia de Diego Saavedra y Magdalena, que había sido nombrado Director General de Marruecos y Colonias en noviembre de 1928. Según F.-Fígares, el film «recoge imágenes de los 'logros' coloniales: laboratorios, edificios oficiales en Santa Isabel [la capital de Fernando Poo, hoy Malabo], plantaciones, explotaciones madereras en la isla y en el continente, establecimientos religiosos y misioneros. Se incluyen planos de carácter etnográfico, como fiestas carnavalescas, instrumentos musicales, peinados de mujeres indígenas» ${ }^{67}$. El historiador Alberto Elena anota que este film es quizás el único que puede compararse con las muy abundantes y notables producciones documentales etnográfico-coloniales francesas o británicas que sobre el continente africano se ruedan durante aquellos años ${ }^{68}$.

\section{El pabellón de la Guinea española}

El pabellón de Guinea de la exposición sevillana ocupa 2.832 metros cuadrados, levantados sobre una parcela de 3.400; es, por tanto, bastante mayor que el marroquí. Estas cifras, sin embargo, no deben confundirnos, ya que en realidad buena parte de esa superficie la ocupa un gran patio central en el que, como veremos, representan su propia existencia varias decenas de nativos guineanos. Su arquitecto es José Granados de la Vega y se construye con la financiación de la Dirección General de Marruecos y Colonias ${ }^{69}$. Según la guía oficial, la «idea de conjunto» del pabellón es obra del ingeniero agrónomo Emilio

\footnotetext{
excesivamente irónica, Nerín, Gustau: Guinea Ecuatorial, bistoria en blanco y negro. Hombres blancos y mujeres negras en Guinea Ecuatorial (1843-1968), Barcelona, Península, 1998.

${ }^{65}$ A diferencia de lo que ocurre con el protectorado marroquí, los filmes que se ruedan en Guinea no incluyen parcela alguna de promoción turística, por obvias razones de carácter geográfico y por la carencia absoluta de infraestructuras.

${ }^{66}$ F.-Fígares Romero de la CruZ, María Dolores: Op. cit., p. 221.

${ }^{67}$ Ibidem: p. 222.

68 ELENA: Op. cit., pp. 19-20, nota 15.

69 SALAS: Op. cit., p. 119.
} 
Gómez Flores y el proyecto decorativo es responsabilidad del artista Vicente $Z_{\text {Zubillaga }}{ }^{70}$. Aunque ya indicamos que la prensa hacía mención al carácter supuestamente nativo del tipo de estructura levantado, lo único que le confiere «autenticidad» son los materiales empleados: maderas y fibras vegetales. Por lo demás, su diseño aparenta ser el resultado de una muy libre y neocolonial recreación de unas supuestas arquitecturas «exótico-primitivas», sin que se atisbe nada parecido a una inspiración con base realmente etnográfica.

La mayor parte de los objetos, si no todos, que habrían de mostrarse en este pabellón arriban a Sevilla en agosto de 1928, en el vapor Joaquín Piélago. La prensa menciona el desembarco de plantas, muebles, "objetos artísticos», armas, animales disecados e incluso de un leopardo y un chimpancé vivos, que estaban al cuidado de varios nativos integrados en la policía colonial ${ }^{71}$. Si únicamente conociéramos esta información o si, peor aún, nos limitáramos a revisar lo poquísimo que acerca del pabellón guineano se anota en la historiografía moderna sobre la exposición, deberíamos concluir que la exhibición de la Guinea española carece de reclamo alguno que pueda llamar la atención sobre la empresa colonial. Pero la realidad fue muy distinta. Es cierto que el pabellón no puede mostrar un estado de desarrollo socioeconómico que no se ha conseguido ni en el continente ni aún en Fernando Poo; sin embargo, el modelo de exhibición diseñado por la administración colonial en el golfo de Guinea resulta bastante más elaborado — pese a todas las limitaciones existentes- de lo que se pudiera pensar, sobre todo si se asume como un hecho cierto la tradicional desidia colonial hispana. Dado que la información disponible al respecto es prácticamente nula, no está de más reproducir la descripción que $\mathrm{R}$. Montalbán ${ }^{72}$ hace del pabellón en la revista Africa, en junio de 1929:

El edificio principal, rodeado de amplia galería en sus cuatro fachadas, tiene en su interior cuatro salones de 8 metros de anchura, dos de $22 \mathrm{~m}$. de largo y dos de 30 m., que dejan en el centro del edificio un patio rectangular rodeado de cuatro galerías que dan acceso a cada uno de los salones que a su vez comunican entre sí. El conjunto del edificio va cubierto con nipa (cubierta indígena formada por paños de hojas largas enlazadas) y armadura de madera; está rematado por cuatro torres situadas en los ángulos. La tablazón que forman las paredes de la galería ha sido recubierta con corteza de árbol recibida de Fernando Poo y tanto las galerías exteriores como las de los salones y torres van decoradas con dibujos inspirados en los trazados por los indígenas del Ecuador [del Ecuador africano] en las paredes de sus viviendas.

\footnotetext{
70 Exposición Ibero-Americana. Sevilla (España) 1929-1930, p. 65.

71 «Para el pabellón de la Guinea española en la Exposición de Sevilla» en Revista Hispano Africana (Madrid) 8-9 (agosto-septiembre de 1928) p. 17.

72 Montalbán, Ramón: «La Guinea Española en la Exposición Ibero-Americana de Sevilla» en Africa. Revista de Tropas Coloniales (Ceuta) 54 (junio de 1929) pp. 142-143. El autor del artículo firma únicamente con sus iniciales: «R.M.». En la trascripción se corrigen las erratas evidentes, la acentuación y la puntuación.
} 
En el salón de entrada, pavimentado con madera de caoba y nogal procedente de la Colonia, se ha instalado un zócalo de madera de okume, colocándose seis vitrinas centrales y cuatro bancos de nogal, también de Guinea, habiéndose expuesto en las vitrinas utensilios domésticos, pipas, armas y herramientas, adornos, brazaletes, collares, varios fetiches y caretas de madera y unos colmillos de elefante labrados en Elobey ${ }^{73}$ con escenas de las excursiones por el continente del General Barrera, Gobernador general que fue de aquellos territorios.

En el mismo salón se exponen cuatro mapas de la Isla de Fernando Poo, Guinea Continental, territorio del Sahara y situación general de nuestras colonias en el Continente africano; estos mapas han sido pintados al estilo antiguo con ilustraciones que dan idea de la configuración general del terreno, cursos de agua, flora y fauna de cada región. Un modelo de casa indígena de nipa y bambú se exhibe en el centro del salón y completa el conjunto del mismo.

En el salón de la derecha se han expuesto algunos ejemplares de la fauna de aquel país, destacándose entre todos un grupo de cuatro gorilas de gran tamaño procedente de nuestra Colonia y que sin duda es de lo más interesante expuesto y de lo que más ha llamado la atención del público; un grupo de iguanos, unos turacos, unos mirlos metálicos, un mono de cara azul, un elefante pequeño, un armadillo y una interesante colección de insectos forman el conjunto expuesto de la fauna de la Colonia ${ }^{74}$. En el mismo salón se han instalado los stands de las sociedades «Bayer» de productos farmacéuticos, que presenta varios gráficos, fotografías y demostraciones de sus preparados contra las enfermedades tropicales; "Constructora Colonial» y «Compañía Colonial de África» que expone productos de sus fincas de la Isla de Fernando Poo y chocolates diversos fabricados con cacao de su cosecha.

En el salón de la izquierda se ha instalado el stand de la Sociedad Colonial de Guinea, exportadora de maderas de la Guinea Continental, que expone diversos ejemplares de las maderas que suministra; dos habitaciones, un comedor y un despacho construidos con madera de la Colonia y el stand de los Misioneros Hijos del [Inmaculado] Corazón de María.

En el salón del fondo se presenta un modelo a escala 1 a 20 del patio de una finca de cacao en la época de la recolección, cuyas dimensiones son 4,50 por 12 metros y en el que se presenta la ejecución de las diversas operaciones de desgranado, fermentación y secado del cacao y se muestran las construcciones típicas de casas utilizadas en aquel país por los agricultores europeos, capataces y braceros indígenas y demás dependencias de la explotación.

Un cayuco ${ }^{75}$ de okume de 14 metros de largo labrado, de un solo tronco, diversas fotografías de paisajes y escenas típicas, varios muebles construidos con lianas en la Colonia y una colección de muestras de madera en la que se presentan ejemplares pulimentados en parte y barnizados en parte y grandes trozos de okume dan idea de una de las principales riquezas que hoy se explota en la Colonia y que tan vasto horizonte ofrece a los que se dedican a su extracción y tan di-

73 Isla del grupo de las Corisco.

74 «Iguanos»: iguanas; «turaco»: ave tropical africana de la que existen numerosas especies; «mirlo metálico»: ave también conocida como «estornino esmeralda», por poseer un plumaje de tono azulado verdoso con reflejos metálicos.

75 Tipo de embarcación fabricada con un tronco de árbol. 
versas aplicaciones tiene en construcción y ebanistería, como se muestra en las diversas secciones del Pabellón Colonial.

La información que acabamos de presentar es concluyente: la administración colonial recurre a un modelo expositivo en el que las severas limitaciones de la empresa «civilizadora» llevada a cabo por España en Guinea quedan casi totalmente ocultas a los ojos del público. En efecto, un primer salón destinado a la exhibición de colecciones etnográficas, mapas de la colonia y un modelo de vivienda nativa — presentado todo ello casi con total seguridad por el Gobierno General de la colonia o la Dirección General de Marruecos y Colonias (DGMC)resume y justifica los empeños de dicha administración. Lo que se muestra no es sólo escaso en términos cuantitativos, sino que tampoco parece que fuera relevante por su calidad; pero es que apenas podía presentarse nada más. Por ello, un segundo salón, el que acoge ejemplares disecados de la fauna guineana, sirve para envolver la iniciativa colonial en un cierto halo de empresa científica, aunque por aquellas fechas no se ha organizado aún ningún estudio verdaderamente científico de la fauna o la flora de aquellos territorios y tampoco se han abordado trabajos oficiales vinculados con la etnología o la antropología. Pero lo que en realidad importa es el escenario que se ha organizado, y lo cierto es que en este salón destacan sobremanera los cuatro gorilas cazados en la colonia cuyas pieles había preparado en Madrid el conocido taxidermista Luis Benedito, quien también trabaja durante aquellos años en el famoso ejemplar de elefante africano que todavía hoy exhibe o, al menos, conserva, el Museo Nacional de Ciencias Naturales, institución que fue la responsable de esta sección naturalista del pabellón. En estos dos salones y en sus contenidos se concentra la participación estrictamente oficial de la administración: poco, sí, pero quizás bien aprovechado. Compartiendo el espacio de una de estas salas nos encontramos con la presencia de tres destacadas empresas privadas: la químico-farmacéutica alemana Bayer, la «Constructora Colonial» y la cosechera "Compañía Colonial de África». De la primera no es necesario hacer ahora valoración alguna; parece que sólo está interesada en la comercialización de sus productos, aunque quizás desarrolle alguna actividad vinculada con la explotación de recursos botánicos de interés farmacéutico. Tampoco podemos decir nada sobre la nacionalidad de los capitales de las otras dos empresas citadas y de la que comparte con los misioneros el tercer salón, la maderera «Sociedad Colonial de Guinea». Antes de comentar la participación misionera, es necesario mencionar la reproducción de una finca de cacao que se exhibe en el cuarto salón del pabellón. Como el conjunto de la instalación expositiva, seguramente fue financiada por la DGMC y su finalidad no pudo ser únicamente la de documentar una de las más características actividades productivas de la colonia, sino que debió de proponerse llamar la atención de posibles emprendedores acerca de la explotación de tan exótico producto. En todo caso, es muy probable que este aplaudido modelo de finca de cacao tuviera mayor interés como documento etnográfico-comercial que como reclamo para inversionistas.

Nos resta una última sección o espacio expositivo: el que ocupan los claretianos, es decir, los Misioneros Hijos del Inmaculado Corazón de María, la 
congregación que fundara quien fuera confesor de Isabel II, el P. Antonio María Claret. Los Misioneros del Corazón de María se instalan en Fernando Poo en 1883, manteniéndose de forma ininterrumpida hasta la actualidad, tanto en Bioko como en el territorio guineano continental. Llegan once años después de que hubieran abandonado la isla los pocos jesuitas que habían logrado sobrevivir a las enfermedades y al desinterés de las autoridades metropolitanas tras la instalación allí de la Compañía de Jesús en 1858. A diferencia de lo sucedido con los jesuitas, los claretianos consiguen poner en marcha y desarrollar su labor misional con notable éxito, gracias sobre todo a que optan por un modelo de misión muy diferente del que articulan sus predecesores. Como señalan Creus y Brunat, se trata de una "Misión de Estado, subvencionada por el Ministerio de Ultramar y utilizada provisionalmente para asegurar la presencia oficial en Guinea» ${ }^{76}$. Los dos rasgos más sobresalientes de la congregación claretiana y de su práctica misionera son «el ultramontanismo (entendido en el sentido de sujeción de la sociedad civil a los principios religiosos) y el regeneracionismo (entendido como la necesidad de un cambio general de costumbres, igualmente para su sujeción a los mismos principios). El primero, se avenía perfectamente al concepto de Misión de Estado; el segundo, formaba parte de una tradición claretiana de misiones interiores [...] ${ }^{77}$. Lo más relevante de este mecanismo socio-religioso de cristianización es que, en teoría, se acopla de forma casi perfecta a un proyecto oficial de colonización, ya que pone las bases para «la integración de un sector importante de la población autóctona en el sistema productivo colonial» ${ }^{78}$. Sin embargo, en la práctica las relaciones con la administración colonial insular fueron tensas, sobre todo durante el primer cuarto de siglo. El conflicto se explica porque es precisamente la muy conservadora congregación claretiana la que defiende un modelo de integración de la población guineana, de la élite por ellos formada, en el proyecto colonial; por contra, el estamento administrativo insular, que tiende a ser teóricamente de orientación liberal, defiende un modelo de sociedad colonial basado en la atracción de colonos españoles y el empleo de una mano de obra africana pero mayoritariamente no guineana. A finales de la década de 1920 el conflicto parece superado. Los claretianos continúan con su propio modelo de cristianización generalizada y socialización e institucionalización político-religiosa de un estamento nativo privilegiado, aceptando en buena medida que esa élite se desarrolle social y políticamente en un contexto paralelo al que articula la sociedad colonial auspiciada por la administración. Esta, por su parte, asume el modelo evangelizador claretiano porque, si bien no se adecua de forma precisa a su diseño de colonización, contribuye a consolidar la presencia hispana en unos

${ }^{76}$ Creus, Jacint; Brunat, M. Antònia: «Introducción» en P. Ermengol Coll, CMF, Crónica de la casa-misión de Santa Isabel, San Vicente de la Barquera, Vic, CEIBA, Documentos de la Colonización, 3 (1997) pp. 7-17 (p. 10).

77 Ibidem: pp. 11-12.

78 Ibidem: p. 13. 
territorios en los que el proceso hispanizador no será nunca el punto fuerte de la práctica colonial ${ }^{79}$.

Veamos ya cuáles son los contenidos del pabellón misional según se recoge en la revista claretiana El Misionero ${ }^{80}$ :

El Stand de las Misiones consta de mesa central y las laterales, con dos atriles giratorios, uno para vistas y otro para libros, con una gran cantidad de mapas, gráficos y objetos expuestos en las paredes y en las bases de las mesas. Llaman la atención grabados del siglo XVI relativos a Fernando Poo, la multitud de libros en lenguas indígenas de Guinea, la colección de documentos pontificios y civiles, la maqueta de la Catedral del Corazón de María de Santa Isabel, el mapa del litoral que nos disputaba Francia y que, recorrido palmo a palmo, trazó el P. Jacinto García; la cabeza del elefante en estado semifósil, los [sic] cráneos grandes de los pamues, uno de ellos trepanado, el calendario histórico de Annobón, esteras y otras manufacturas del país, etc. Es el pabellón preferido por los visitantes sevillanos y extranjeros. Han recibido muchas felicitaciones los organizadores ${ }^{81}$, Sres. Bárcenas, Monis, Montalbán, Pittaluga ${ }^{82}$ y el [claretiano] P. [Juan] Postius.

La instalación de los Misioneros del Corazón de María en la exposición sevillana refleja de forma bastante ajustada el mecanismo que articula las relaciones existentes entre religiosos y administración civil. De un lado, exhibe objetos que suelen atraer la atención del público sin demasiada dificultad en cualquier exposición: algún ejemplar de la fauna autóctona, exóticas y singulares manufacturas nativas y cráneos humanos de individuos supuestamente salvajes» $^{83}$. La todavía no muy intensa materialización de la actividad misional en el golfo queda representada por una maqueta de la catedral claretiana, documentos religiosos y el

79 En el ámbito de la evangelización hispano-católica de los territorios guineanos, es significativo que sea precisamente en 1929, concretamente el 28 de agosto, cuando se ordene el primer sacerdote nativo, Joaquín María Sialo. Se recoge información detallada al respecto en las dos revistas editadas por los claretianos: La Guinea Española y El Misionero, entre agosto y octubre de 1929.

${ }^{80}$ El Misionero (Madrid) 70 (julio de 1929) p. 161. Es necesario anotar que la congregación tuvo que duplicar sus esfuerzos para poder estar presente tanto en la exposición de Sevilla como en la de Barcelona, pues en esta última se organiza durante el segundo semestre de 1929 una gran exposición misional que cuenta también con una destacada participación de la misión claretiana en la Guinea española. Cf. SÁNCHEZ Gómez, Luis Ángel: «Martirologio, etnología y espectáculo: La Exposición Misional Española de Barcelona (1929-1930)», en Revista de Dialectología y Tradiciones Populares (Madrid) LXI-1, (2006), pp. 63-102.

81 No nos queda claro si los organizadores que se citan son los responsables de la sección misional o del conjunto del salón, en el que también presenta sus colecciones el Museo de Ciencias Naturales.

82 Debe de tratarse del médico español de origen italiano Gustavo Pittaluga Fattorini (18761956), catedrático de parasitología y patología tropical de la Facultad de Medicina en la Universidad de Madrid, exiliado a Cuba tras la Guerra Civil de 1936.

83 Son cráneos de pamues del continente, gentes consideradas especialmente refractarias a la civilización. Es de suponer que los misioneros nunca habrían expuesto cráneos de nativos cristianizados. 
inevitable repertorio de obras litúrgicas en lenguas nativas. Por último, el pabellón hace gala de la implicación de los misioneros en la política oficial, a través de la exhibición de mapas y documentos civiles que contribuyen a la consolidación de la presencia hispana en aquellos territorios.

\section{La exhibición de nativos guineanos}

El renovado modelo de colonialismo «tropicalista» que exhibe el pabellón guineano difiere de forma sensible del no menos «moderno» que se despliega en el marroquí, circunstancia que no hace sino reflejar, como ya adelantamos, lo tanto o más distantes que están las estructuras históricas y contemporáneas de colonización de ambos territorios. Para los militares y los escasos políticos y burócratas españoles relacionados con el ámbito colonial, los territorios guineanos y los del protectorado marroquí son mundos no sólo distantes sino profundamente distintos. Ambos pueden estar habitados por «infieles», es cierto, pero los marroquíes — tanto árabes como bereberes ${ }^{84}$ — forman parte de una civilización que, cuando así conviene, se considera «hermana»: sus antepasados habían dado muestras de innegables dotes políticas, militares y artísticas, habían dejado un rico legado en tierras peninsulares y puede que incluso existieran vínculos entre españoles y marroquíes desde la prehistoria ${ }^{85}$. Sus posibilidades de desarrollo y progreso, y con ello las de los colonizadores, parecen innegables. Nada similar puede decirse de Guinea. Allí, el único proyecto es cristianizar a sus «salvajes»e «infantiles» pobladores y explotar «racionalmente» sus recursos humanos y medioambientales.

De lo anteriormente anotado cabe deducir que la participación de nativos guineanos en el certamen responde inevitablemente a mecanismos de representación muy diferentes a los desplegados con la población marroquí que también participa en la exposición. Todo apunta a que los marroquíes presentes en su pabellón —e incluso en el «Barrio Moro»— son esencialmente artesanos y comerciantes, a los que se suman algunos miembros de la milicia como servicio de guardia. Es evidente que las facciones físicas y, sobre todo, la indumentaria de todos estos personajes son un auténtico espectáculo para los visitantes, pero hemos de reconocer que su presencia en Sevilla tiene una motivación en principio no meramente exhibicionista. El caso guineano es bien diferente. Una nota de prensa de la Revista Hispano-Africana ${ }^{86}$ nos presenta lo que allí se podría con-

${ }^{84} \mathrm{La}$ manipulación y recreación colonialista de las presuntas cualidades y aptitudes diferenciadas entre árabes y bereberes es un tema interesante y complejo que comenta MATEO DIESTE: Op. cit., pp. 107-118.

85 Cf. Fernández Martínez, Víctor: «La idea de África en el origen de la prehistoria española: una perspectiva postcolonial» en Complutum (Madrid) 12 (2001) pp. 167-184.

86 «El pabellón de Guinea en la Exposición de Sevilla» en Revista Hispano-Africana (Madrid) 2 (febrero de 1929), p 12. A partir de 1929 el título de la revista añade el guión entre los dos adjetivos. 
templar tras la apertura del certamen: «Junto al pabellón habrá una gran extensión de terreno en el que bajo las plantas de los trópicos harán su vida habitual varias familias de la raza bubi ${ }^{87}$, trabajando en sus rudimentarias industrias, condimentando sus manjares y entregándose a la vista del espectador a sus características danzas, acompañadas con instrumentos del país». En mayo, con motivo de la inauguración, esa misma revista informa de que son medio centenar los hombres y mujeres presentes: «Aparecían descalzos y cubiertos desde la cintura para abajo. Estos tipos han sido escogidos entre los más característicos de cada tribu» ${ }^{8}$.

En efecto, el pabellón de Guinea cuenta con la presencia de cincuenta y ocho nativos guineanos pertenecientes a tres grupos étnicos, originarios tanto del continente como del territorio insular: pamues, corisqueños y annoboneses ${ }^{89}$. Extraña la no participación de bubis de Fernando Poo; quizás la administración colonial los consideraba «demasiado civilizados», aunque precisamente esta circunstancia podría haber servido para demostrar los supuestos avances introducidos por los españoles en la isla; siempre, claro está, que esos nativos hubieran participado desarrollando alguna actividad artesanal o de otra índole, no como meros seres singulares que son exhibidos por lo peculiar de sus cuerpos, danzas, cánticos y costumbres cotidianas. También es posible que los misioneros claretianos pusieran alguna objeción a la presencia de bubis, que sin duda formaban parte del grupo étnico sobre el que ejercían una más directa e intensa supervisión.

Ramón Montalbán, el redactor de la revista Africa que nos ofrece la información más detallada sobre el pabellón guineano, anota que la presencia nativa tiene por objetivo dar «al conjunto la nota de color y vida que anime la totalidad, vida que solo los habitantes de aquellos países pueden comunicar con sus vestidos, danzas típicas y ejecución de algunos trabajos de su arte e industria rudimentaria» ${ }^{90}$. Lo que se espera que ofrezcan los guineanos es bien sencillo:

Los grupos de indígenas en el patio central del pabellón ofrecen un golpe de vista sumamente pintoresco que desde el primer día atrajo la atención de todos los visitantes, ejecutando sus danzas típicas acompañadas con la música de sus instrumentos, muchos de ellos raros y absurdos para el europeo y desde luego de lo más rudimentario y primitivo que puede imaginarse: tambores, troncos de ár-

${ }^{87}$ No son bubis los nativos que finalmente llegan a Sevilla. La guía oficial también los menciona, pero se edita antes de la apertura de la exposición y su información no nos resulta digna de confianza.

88 «El pabellón de Guinea en la Exposición de Sevilla» en Revista Hispano-Africana 5 (mayo de 1929) p. 15. El énfasis en la cita es mío.

${ }^{89}$ Se exhibieron hombres y mujeres pamues y corisqueños, y únicamente hombres de Annobon, ya que las mujeres annobonesas eran «muy refractarias a salir de su isla natal», según Ramón Montalbán. El dato concreto del número de guineanos exhibidos se anota en el número 70 , de julio de 1929, de la revista El Misionero (p. 160).

90 Montalbán, Ramon: Op. cit., 143. 
bol huecos que al ser golpeados producen un sonido característico, una guitarra de bambú en la que las cuerdas son fibras de la misma caña y otros análogos ${ }^{91}$.

Este mismo redactor recoge en su escrito algunas observaciones que nos informan del escaso aprecio, del evidente desprecio, que siente ante esas personas, de su ínfima consideración sobre los pobladores de aquellas tierras. La circunstancia inmediata que sirve de excusa al articulista para denigrar a los guineanos llegados a Sevilla es tan puntual y absurda como difícil de comprobar: no manifiestan reacción alguna ante los «logros de la civilización» que supuestamente podían contemplar en la ciudad hispalense. Así lo argumenta el periodista:

Alguien pensará la impresión que habrá causado a estos morenos llegados de las lejanas tierras de Guinea, el ambiente febril y civilizado de nuestras ciudades, sobre todo de Sevilla, donde con motivo de la Exposición se ha reunido cuanto el arte y la técnica moderna son capaces de ofrecer, más quien conoce la especial psicología de los morenos comprende fácilmente que toda nuestra civilización no les causa impresión ninguna, a unos les gusta aprovechar cuanto de útil y agradable tiene y a otros les tiene completamente sin cuidado, pero asombrarse, ninguno 92 .

Pero el asunto no queda ahí, ya que —además de desinteresados y quizás también de desagradecidos_ resulta que los «morenos» son auténticos materialistas, sólo les interesa el dinero:

Todos son fanáticos del moderno dios «Dinero» que tantos adoradores tiene en todas las latitudes; las mujeres pamues que no sabían castellano, enseguida aprendieron la palabra mágica «pesetas». Los morenos más civilizados gastan cuanto dinero cae en sus manos y se lamentan cuando no tienen para entrar en las tiendas a comprar; los hombres del bosque guardan su dinero para comprar allá en su país mujeres, que según dicen, cuestan unos cuantos duros entregados al padre de la interesada93.

Al margen de la despectiva y errónea observación sobre la presunta compra de mujeres ${ }^{94}$, y aunque menciona la multitud de «adoradores» que tiene la peseta, es evidente que el autor del texto no cae en la cuenta de que sus afirmaciones y su negativa valoración sobre la reacción de los «morenos» podrían haber sido aplicadas a cualquiera de los muy civilizados blancos que acudieron

91 Ibidem.

92 Ibidem.

93 Ibidem.

94 Pudiera haber ocurrido, no obstante, que las transformaciones sufridas por determinadas comunidades guineanas, debido sobre todo a la introducción del dinero, hubieran conducido efectivamente a la alteración de los antiguos modelos de «intercambio» de mujeres. 
al certamen hispalense; en realidad, a casi cualquier individuo "contaminado» por la religión que sólo rinde culto al dinero. El alegato racista queda, de este modo, notablemente debilitado.

Por supuesto, el redactor no se interroga en ningún momento por las circunstancias que hacen posible la presencia de ese más de medio centenar de guineanos en Sevilla, ni por las condiciones de su estancia en la ciudad, mejor dicho, en el propio recinto ferial, ya que los guineanos residen en cinco chozas anexas al pabellón. Con tan rústico alojamiento, quizás pretendía la organización que no se corrompiera o desvirtuara su forma de vida tradicional, e incluso pudieron argumentar que no hacían sino asumir los propios deseos de los exhibidos, argumento que también utiliza la administración cuando se opta por alojar en el propio Parque del Retiro de Madrid a los «igorrotes» presentes en la Exposición de Filipinas de 1887. Pero, como luego veremos, ésta es una de las escasas coincidencias que se pueden apreciar entre el certamen colonial decimonónico y el sevillano de 1929. Por otro lado, ya vimos cómo en la Revista Hispano-Africana se afirmaba sin reparo que habían sido «escogidos entre lo más característico de cada tribu», por lo que habría que dudar sobre la voluntariedad de su presencia en Sevilla ${ }^{95}$. Es evidente que la administración colonial no está interesada en mostrar los presuntos progresos de su labor «humanístico-civilizadora» en Guinea, esto es algo que dejan en manos de los misioneros. Las autoridades españolas no pueden alardear de una población nativa «culta», ni siquiera pueden exhibir artesanos con habilidades dignas de atraer la atención de los europeos, algo de lo que está sobrado el pabellón marroquí. Por tanto, la única forma de rentabilizar la presencia de población guineana en Sevilla es mediante su exhibición singularizada en calidad de curiosidad etnográfica y marcadamente «salvajística».

\section{SOBRE ANTIGUOS Y NUEVOS MODELOS DE EXHIBICIÓN COLONIAL}

El estudio de los pabellones guineano y marroquí que hemos esbozado nos va a permitir hacer algunos consideraciones sobre las divergencias que se aprecian entre los modelos de exhibición colonial que España despliega en 1929 y el que había articulado con motivo de la exposición de Filipinas - y las restantes posesiones del Pacífico- en 1887. Se podría afirmar que los más de trescientos años de presencia española en el archipiélago asiático y la forma en la que se lleva a cabo el proceso colonizador durante todo ese tiempo justifican plenamente las diferencias. De hecho, no podemos olvidar que en 1887 la colonización de Guinea se encuentra todavía en una fase embrionaria y que Ma-

95 De manera similar a la revista militar mencionada se expresa la religiosa El Misionero (Madrid) 69 (junio de 1929) p. 135: «Para dar más colorido y viveza al Pabellón se han traído unos 60 indígenas». 
rruecos es aún durante aquellos años un sultanato independiente. Pero al margen y más allá de lo anotado, también es verdad que en 1887 el tradicional y anquilosado modelo de relaciones coloniales establecido por España en Filipinas se encuentra en vías de una notable, aunque no radical, transformación. Las circunstancias y condiciones sociales y económicas en las que se desenvuelve la sociedad colonial se han modificado de forma destacada durante las últimas cuatro o cinco décadas de la centuria, siendo especialmente relevante el progreso logrado por algunos individuos y familias de los estamentos nativos más elevados. En este renovado contexto, ¿puede afirmarse que la exposición filipina de 1887 anticipa el modelo de colonialismo tropical-africanista que se exhibe en Sevilla en 1929? Creo que no.

En la monografía publicada sobre la Exposición de Filipinas, he tratado de justificar de forma sucinta por qué no comparto esa interpretación ${ }^{96}$; ahora, aportaré alguna información complementaria. En la obra citada se anota que la renovación de la administración española en Filipinas en los años ochenta del siglo XIX es algo evidente en lo que se refiere a la aparente modernización general del sistema, a la participación de algunos de los nuevos cuerpos administrativos en el entramado colonial y a los esfuerzos realizados para convertir a las Filipinas en un atractivo referente económico para la Península. Pero todo esto no es comparable con lo que se hace, o se intenta hacer, en África, sobre todo en Guinea, en el siglo XX y con lo que se exhibe en Sevilla en 1929. Es cierto que el espacio «salvajístico» de la exposición de 1887 resulta tremendamente atractivo para el público y que en buena medida reafirma la condición singular de ciertos grupos étnicos del archipiélago. Ahora bien, esa vertiente etnográfica y espectacular

ocupa una parcela muy reducida en comparación con los ámbitos materiales y simbólicos que la administración despliega con el objetivo de presentar las facetas más avanzadas de las gentes de Filipinas y del propio quehacer español en las islas. El énfasis puesto, por ejemplo, en destacar sus producciones artesanales y, con mayor intensidad, las artísticas, está vinculado más directamente con la articulación, o al menos la presentación, de un modelo asimilacionista más o menos caduco o renovado que con un simple proyecto de explotación colonial97.

96 SÁNCHEZ GómEZ: Un imperio, pp. 361-370. En dicho trabajo discuto el planteamiento propuesto al respecto por el historiador catalán Josep Maria Fradera —a quien, al margen de esta puntual discrepancia, considero el investigador que más ha hecho y hace por la renovación de los estudios de historia colonial de España en los últimos años-, en concreto discrepo de su idea de que uno de los principales objetivos de la exposición de 1887 fuera contribuir a que Filipinas se convirtiera «en lo más parecido a las colonias tropicales propias del colonialismo europeo finisecular». Véase FrADERA, Josep Maria: «La política colonial española del siglo XIX (Una reflexión sobre los precedentes de la crisis de fin de siglo)» en Revista de Occidente (Madrid) 202-203 (1998) pp. 183-199.

97 SÁNCHEZ GómeZ: Un imperio, p. 365. 
Por otra parte, ni en $1887 \mathrm{ni}$-menos aún- durante el primer tercio del XX es capaz la administración española de aprovechar los recursos que le puede suministrar el conocimiento etnológico o antropológico de las poblaciones colonizadas; será ya en época franquista cuando se articulen algunos mecanismos de análisis e interpretación social relativamente institucionalizados.

Poco hay, por tanto, en la exhibición de 1929 que recuerde a la de 1887. Por lo que se refiere a la sección guineana, lo único que rememora a la filipina es la recreación de unas supuestas arquitecturas nativas y, sobre todo, la presencia física de gentes traídas desde la colonia. Sin embargo, en Sevilla no se levantan estructuras indígenas, simplemente se recurre a materiales perecederos y a un pretendido estilo neocolonial para construir el pabellón. Quizás las «chozas» habitadas por los guineanos tuvieran un cierto "carácter etnográfico», aunque lo podemos en duda, ya que no parece que nadie se preocupara por fotografiarlas. Por lo que se refiere a la «exhibición humana», sabemos que al Parque del Retiro madrileño llegan en 1887, entre otros, varios nativos etiquetados como «salvajes» o simplemente «infieles» —en el caso de los musulmanesque, ciertamente, no tienen otro cometido que el de exhibir sus gestos, sus rituales y sus propios cuerpos, algo muy similar a lo que ocurre en Sevilla. Los restantes miembros de la «colonia filipina» son trabajadores, artesanos —incluido un escultor - o desarrollan algún tarea concreta durante la exposición. Pero ni siquiera el contexto que rodea la estancia de los «salvajes» filipinos en Madrid es del todo equiparable al que se vincula con la de los guineanos en Sevilla. No tenemos constancia de que existiera debate social, político o periodístico alguno sobre quiénes eran en realidad aquellos individuos africanos de piel oscura y de qué manera se vinculaban con España. No se documentan valoraciones éticas sobre cómo y por qué están en la exposición; y, por supuesto, no cuentan con el apoyo de «compatriotas ilustrados» residentes en la Península, ni tercian en su favor políticos españoles, de cualquier signo político, algo que sí se produce durante la celebración de la exposición filipina ${ }^{98}$. Ni siquiera interesan a los antropólogos, aunque también es verdad que la antropología española no vive entonces el momento expansivo de 188799 . Finalmente, tampoco existe en España grupo político alguno que de una manera firme y resuelta cuestione las iniciativas coloniales que se llevan a cabo en el golfo de Guinea. En último término, los «morenos» guineanos sólo parecen suscitar incomprensión o desprecio. Es significativa la observación hecha por Ramón Montalbán en la revis-

98 Cf. SÁNChez Gómez: Un imperio, pp. 224-264. De todas formas, para confirmar lo que decimos habría que realizar un análisis mucho más detallado de la prensa y sus noticias sobre la exposición sevillana, tarea que no hemos abordado.

99 Hemos de aclarar, no obstante, que si bien es cierto que en la exposición sevillana apenas se atisba la presencia de la práctica científica antropológica, ésta es una circunstancia que en modo alguno resta interés al certamen. En definitiva, más allá de la recreación interesada del universo nativo, quien realmente se exhibe — y de forma harto impúdica - en este tipo de eventos es la propia sociedad metropolitana. 
ta Africa, que ya hemos citado, sobre el presunto desinterés que muestran todas estas personas ante los casi increíbles logros de la civilización occidental que desfilan antes sus ojos durante su estancia en Sevilla, desinterés o apatía que sería buena muestra de su salvajismo y estulticia. Y si por algo nos llama la atención esta valoración, es por el hecho de que cuando arriban los filipinos a Barcelona con motivo de la exposición de 1887, en la prensa se escribe justamente todo lo contrario. Políticos y periodistas parecen enorgullecerse —salvo alguna que otra excepción- de poder mostrar a sus «hermanos» filipinos, aunque algunos de ellos sean «infieles» o «salvajes», los progresos de la madre patria y, al mismo tiempo, esos españoles disfrutan y hasta se envanecen por la favorable y perdurable impresión que todo ello causa en los filipinos ${ }^{100}$.

Y si de la presencia de nativos «invitados» pasamos a valorar los contenidos de ambas exposiciones, de Filipinas y Guinea, las diferencias entre los modelos de colonización y exhibición se disparan. Dejando a un lado el hecho de que la filipina es, obviamente, de tamaño considerablemente mayor y mucho más compleja y completa en todos los sentidos, lo que destaca es la distinta orientación y estructura de ambas. Como ya anotamos en otro lugar al comparar la exposición filipina con otras exhibiciones europeas contemporáneas, la drástica dicotomía que estas últimas establecen «entre población europea y población indígena, entre instituciones y modos de vida de unos y otros, entre colonizadores y colonizados, en definitiva, es algo que no se documenta en la exposición de Madrid» ${ }^{101}$, lo que ciertamente no es obstáculo para que exista «en la práctica una cierta diferenciación entre los planos estrictamente indígenas - ya sean cristianos, musulmanes o paganos - y los contextos de la sociedad colonial de origen español o, sencillamente, occidental» ${ }^{102}$. En la exhibición guineana de Sevilla, sin embargo, ni siquiera es posible reflejar o reconocer fronteras entre los distintos estamentos de la sociedad colonial porque no se exhibe realmente ninguna sociedad colonial. Se observan tres planos vitales que nunca se encuentran: un mundo de «morenos salvajes» visto a través de unos pocos artefactos, «extraños»y no menos salvajes que sus propietarios; un segundo territorio - geográfico, humano y espiritual_ monopolizado por los misioneros; y un tercer y último espacio de explotación económica pura y dura que en ningún momento se imbrica en un entramado social-colonial reconocible. Es imposible, por tanto, que en Sevilla se presenten los «progresos» de una población nativa aculturada, como sí se hace, y de forma exitosa, en 1887 , especialmente a través de las creaciones de algunos afamados pintores filipinos. Por último, hemos de llamar la atención sobre la presencia en Sevilla de un stand misionero, recurso que podemos calificar de verdadero ejemplo de modernidad. En 1887 no hay stand misionero alguno, ni siquiera se documenta una participación oficial de las órdenes religiosas en cuanto tales, aunque sí están presentes con dis-

\footnotetext{
100 SÁNCHEZ GómEZ: Un imperio, p. 58.

101 Ibidem: 308.

102 Ibidem.
} 
tintos materiales algunos religiosos a título particular. Por supuesto, entonces era inconcebible la propia idea del stand, pero quizás haya algún rasgo diferencial más. Los misioneros claretianos son conscientes de que apenas existe una sociedad colonial en Guinea, de que su labor se desarrolla en buena medida de forma paralela, en ocasiones enfrentada, al propio modelo de colonización. También ellos han de mostrar de forma claramente reconocible su labor socialcristianizadora, por lo que no dudan en "exponerse», en defender y publicitar su quehacer de una manera muy cercana a lo comercial.

Vayamos ahora a la sección marroquí. Antes de nada, hemos de hacer una anotación que no por obvia deja de ser relevante: la presencia de España en el norte de Marruecos entre 1912 y 1956 se justifica en la fórmula del protectorado. No se trata estrictamente de un territorio colonial ni de una "provincia de Ultramar», sino de una figura jurídica que surge de un tratado internacional firmado entre un estado protegido y un estado protector. En el caso que nos ocupa, el estado protegido es el sultanato de Marruecos y el estado protector son en realidad dos: Francia y España ${ }^{103}$. Por tanto, Marruecos no es formalmente una colonia. De hecho, la única publicación oficial que conocemos que hace mención al Pabellón colonial de la exposición es el folleto que con ese título edita la Dirección General de Marruecos y Colonias, qué sólo ofrece información - muy general, de carácter histórico, geográfico y comercial- sobre los territorios del golfo de Guinea, los únicos que se consideran y se reivindican como estrictamente coloniales ${ }^{104}$.

Que los territorios ocupados y administrados por España en el norte de África tengan carácter de protectorado no es obstáculo para que la metrópoli, el estado «protector», desarrolle determinadas políticas y ciertos modelos de intervención socioeconómica muy similares o idénticos a los que podría articular si se tratara de una simple colonia. Lo que ocurre es que las iniciativas puestas en práctica en Marruecos y en Guinea en ningún caso podrían haberse desarrollado por cauces paralelos, incluso aunque Marruecos hubiera sido pura y simplemente una colonia. Así, a pesar de que haya impuesto su dominio con la fuerza de las armas, España ha de asumir la existencia de unas autoridades na-

${ }_{103}$ Mateo Dieste, Op. cit., pp. 70-78, hace un ajustado análisis del modelo jurídico-político del protectorado español en Marruecos.

104 Pabellón Colonial. Exposición Iberoamericana. Sevilla 1929, Madrid, Presidencia del Consejo de Ministros, Dirección General de Marruecos y Colonias, 1929. Ésta es la única publicación oficial que ofrece información específica sobre la parcela colonial de la exposición sevillana. Este dato es buena prueba de la incapacidad de que hace gala la administración para sacar provecho de la investigación o la alta divulgación en materia colonial. Tal estado de cosas contrasta de forma radical con la actividad publicista desarrollada por Portugal, tanto en el ámbito de la exposición colonial de Oporto, de 1934, como en relación con la presencia lusa en Sevilla, con motivo de la cual se edita un buen número de catálogos y trabajos vinculados con su práctica colonial. Sobre la exposición de Oporto se puede encontrar información general en CABRITA, Luísa: "A primeira exposição colonial portuguesa. Porto 1934» en J. A. Mourão, A. M. Cardoso de Matos y M. Estela Guedes, O mundo ibero-americano nas grandes exposições, [Lisboa], Vega (1998) pp. 191-207. 
tivas marroquíes que se extienden desde los caídes de las cabilas al jalifa, lo que de algún modo obliga a la administración hispana a afrontar con ciertas dosis negociadoras determinadas actuaciones ${ }^{105}$.

Centrándonos ya en el análisis del modelo expositivo del pabellón marroquí, las diferencias con lo visto en Madrid en 1887 continúan siendo radicales, aunque en este caso también lo son con respecto a la propia exhibición guineana. La exhibición pública de la labor española en Marruecos se encauza de forma decidida a través de la presentación de las iniciativas de promoción educativa y cultural de la población. El cuerpo central del discurso expositivo descansa sobre lo que se considera más «adecuado» para un pueblo que, pese a todo, aún se cataloga como «inferior»: el desarrollo de las enseñanzas de «artes y oficios», que se asumen como especialmente provechosas en un país que ofrece ejemplos espectaculares, tanto históricos como contemporáneos, de labores artesanas. Sin embargo, y a diferencia nuevamente de lo que ocurre en Madrid en 1887, no es factible mostrar las creaciones, y mucho menos los logros artísticos, de una sociedad verdaderamente hispano-marroquí: sencillamente no existen. En otro orden de cosas, aunque sabemos que hubo cánticos y danzas, la exhibición de la población marroquí tiene un carácter muy diferente a la guineana: como ya adelantamos, aquéllos son, al menos en teoría, profesionales que desarrollan su quehacer de cara al público, nada más. Por otra parte, residen en un auténtico hotel levantado en el recinto del «Barrio Moro», no en simples chozas, como ocurre con los nativos de Guinea. Finalmente, en el pabellón marroquí no hay representación misional: definitivamente, España había renunciado a competir con el islam.

Como balance final, podemos concluir que, por lo que puede contemplarse en Sevilla en 1929, ese nuevo imperio hispano-africano imaginado por determinados personajes y grupos durante el primer cuarto del siglo XX está muy lejos no sólo de ser entonces una realidad, sino de poder serlo en un futuro más o menos próximo. Desde luego, prácticamente nada hay que recuerde antiguas «glorias imperiales» y tampoco existen cauces que puedan reconducir la presencia de España en África hacia algo parecido, ni de lejos, a lo que hasta hacía sólo unas décadas había sido la presencia española en el Caribe o, incluso, en el Pacífico. Pese a todo, las circunstancias y la intensidad de la empresa colonizadora se modifican de forma notable durante la época franquista, especialmente en relación con Marruecos. Pero ése es un momento y un contexto que necesariamente han de quedar fuera del acercamiento a la exposición sevillana que ahora concluimos.

${ }^{105}$ El jalifa es el personaje nombrado por el sultán para administrar el territorio de protectorado español. No obstante, el sultán sólo puede elegir entre los dos candidatos propuestos por las autoridades españolas. La más detallada, y reciente, exposición sobre la estructura organizativa del protectorado es la redactada por VillanOVA, José Luis: El Protectorado de España en Marruecos. Organización política y territorial, Barcelona, Bellaterra, 2004. 